\title{
Assessing the Effect of Persistent Organic Pollutants on Reproductive Activity in Common Dolphins and Harbour Porpoises
}

\author{
S. Murphy*1, G. J. Pierce ${ }^{2,3}$, R. J. Law ${ }^{4}$, P. Bersuder ${ }^{4}$, P. D. Jepson ${ }^{5}$, J. A. Learmonth ${ }^{2}$, \\ M. Addink ${ }^{6}$, W. Dabin ${ }^{7}$, M. B. Santos ${ }^{3,2}$, R. Deaville ${ }^{5}$, B. N. Zegers ${ }^{8}$, A. Mets ${ }^{9}$, E. Rogan ${ }^{10}$, \\ V. Ridoux 9 , R. J. Reid ${ }^{11}$, C. Smeenk ${ }^{6}$, T. Jauniaux ${ }^{12}$, A. López ${ }^{13}$, J. M. Alonso Farré13 A. F. \\ González $^{14}$, A. Guerra ${ }^{14}$, M. García-Hartmannn ${ }^{6,15}$, C. Lockyer ${ }^{16}$, and J. P. Boon ${ }^{9}$ \\ ${ }^{1}$ Sea Mammal Research Unit, Scottish Oceans Institute, University of St Andrews, \\ St Andrews, Fife, KY16 8LB, UK. Email: snm4@st-andrews.ac.uk \\ ${ }^{2}$ School of Biological Sciences, University of Aberdeen, Tillydrone Avenue, Aberdeen AB24 2TZ, UK \\ ${ }^{3}$ Instituto Español de Oceanografía, Centro Oceanográfico de Vigo, P.O. Box 1552, 36200, \\ Vigo, Spain \\ ${ }^{4}$ Cefas Lowestoft Laboratory, Pakefield Road, Lowestoft, Suffolk NR33 0HT, UK \\ ${ }^{5}$ Institute of Zoology, Zoological Society of London, Regent's Park, London, NW1 4RY, UK \\ ${ }^{6}$ National Museum of Natural History, Darwinweg 22300 RA, Leiden, The Netherlands \\ ${ }^{7}$ Centre de Recherche sur les Mammifères Marins, Port des Minimes, Avenue Lazaret, \\ 17000 La Rochelle, France \\ ${ }^{8}$ Royal Netherlands Institute for Sea Research (NIOZ), P.O. Box 59, 1790 AB Den Burg, \\ Texel, The Netherlands \\ ${ }^{9}$ Centre de Recherche sur les Ecosystèmes Littoraux Anthropisés ,UMR 6217 CNRS-IFREMER- \\ Université de la Rochelle, 22 avenue Michel Crépeau, 17042 La Rochelle, France \\ ${ }^{10}$ AFDC, Department of Zoology, Ecology and Plant Science, University College Cork, Cork, Ireland \\ ${ }^{11}$ Wildlife Unit, SAC Veterinary Services, Drummondhill, Stratherrick Road, \\ Inverness, IV2 4JZ, Scotland \\ ${ }^{12}$ Department of Pathology, University of Liege, Liege, Belgium \\ ${ }^{13}$ CEMMA, Apdo. 15 - 36380 Gondomar, Pontevedra, Spain \\ ${ }^{14}$ Instituto de Investigaciones Marinas (CSIS), Eduardo Cabello 6, 36208 Vigo, Spain \\ ${ }^{15}$ Elephant house, Muelheimer Str. 273, 47058 Duisburg, Germany \\ ${ }^{16}$ Age Dynamics, Huldbergs Allé 42, DK-2800 Kongens Lyngby, Denmark.
}

Murphy, S., G. J. Pierce, R. J. Law, P. Bersuder, P. D. Jepson, J. A. Learmonth, M. Addink, W. Dabin, M. B. Santos, R. Deaville, B. N. Zegers, A. Mets, E. Rogan, V. Ridoux, R. J. Reid, C. Smeenk, T. Jauniaux, A. López, J. M. Alonso Farré, A. F. González, A. Guerra, M. García-Hartmann, C. Lockyer, and J. P. Boon. 2010. Assessing the effect of persistent organic pollutants on reproductive activity in common dolphins and harbour porpoises. J. Northw, Atl. Fish. Sci., 42: 153-173. doi:10.2960/J.v42.m658

\begin{abstract}
As top predators, marine mammals can provide information on the accumulation of anthropogenic toxins which present the greatest risk to consumers. We assessed the impacts of persistent organic pollutants (POPs) on two cetacean species that feed on commercially important fish species in the eastern North Atlantic; the common dolphin (Delphinus delphis) and the harbour porpoise (Phocoena phocoena). In order to evaluate the possible long-term effects of POPs on the continued viability of these populations, we investigated their effects on reproductive activity in females, using ovarian scars as an index of reproductive activity. In harbour porpoises, high POP burdens tended to be associated with lower ovarian scar number, possibly indicating that high contaminant levels were inhibiting ovulation, or some females may go through a number of infertile ovulations prior to a successful pregnancy, birth, and survival of their first offspring during early lactation. In contrast, initial results identified that the common dolphins with contaminant burdens above a threshold level for adverse health effects in marine mammals $\left(17 \mu \mathrm{g} \mathrm{g}^{-1}\right.$ total PCBs lipid) were resting mature females, with
\end{abstract}

*Corresponding Author 


\begin{abstract}
high numbers of ovarian scars. This suggests that (a) due to high contaminant burdens, females may be unable to reproduce, thus continue ovulating, or (b) females are not reproducing for some other reason, either physical or social, and started accumulating higher levels of contaminants. Additional analyses were carried out on a control group of "healthy" D. delphis, i.e. stranded animals diagnosed as bycatch and were assessed for evidence of any infectious or non infectious disease that would inhibit reproduction. Results suggested that high contaminant burdens, above the threshold level, were not inhibiting ovulation, conception or implantation in female $D$. delphis, though the impact on the foetal survival rate (in both species) requires further examination. Investigations into accumulation and persistence of ovarian scars and use as an index of reproductive activity were also undertaken within this study.
\end{abstract}

Keywords: corpora albicantia, corpora lutea, Delphinus delphis, health, ovarian scars, persistent organic pollutants, Phocoena phocoena, reproduction

\section{Introduction}

Organochlorine compounds (OCs), such as polychlorinated biphenyls (PCBs) and DDT, accumulate in the blubber of marine mammals, and a large number of these lipophilic substances are known to be hormone or endocrine disrupters. The endocrine and reproductive effects of these chemicals are believed to be due to their ability to: (a) mimic the effect of endogenous hormones; (b) antagonize the effect of endogenous hormones; (c) disrupt the synthesis and metabolism of endogenous hormones; and (d) disrupt the synthesis of hormone receptors (Amaral Mendes, 2002). OCs have been reported to increase susceptibility to infection (Jepson et al., 2005; Hall et al., 2006a), which may have consequences not only on adult survival but also on uterine and placental health and, subsequently, foetal health and survival (Hohn et al., 2007). Reproductive effects linked with exposure to endocrine disruptors such as PCBs and associated DDT-like compounds include decreased fecundity, implantation failure and sterility (caused by stenosis, occlusions and leiomyomas) in seals (Helle, 1976; Helle et al., 1976; Reijnders, 1986; Olsson et al., 1994; Reijnders, 1999; Bredhult et al., 2008); premature pupping in sea lions (DeLong et al., 1973); and also severe reproductive dysfunction through the development of cancer and possibly hermaphroditism in beluga whales (Delphinapterus leucas) (Martineau et al., 1987; De Guise et al., 1994; Reijnders, 1999). The findings of these studies however, although strongly suggestive, have not been conclusive as the etiology of the observed disorder has usually been uncertain (Reijnders, 2003).

PCBs and DDT are persistent organic pollutants (POPs), substances that persist in the environment, and uptake of POPs in marine mammals occurs predominately through prey consumption. POPs are reported to both biomagnify and bioaccumulate, as their concentration increases from one trophic level to the next, within the food chain. Not only does an individual's POP burden reflect its dietary preferences, it is influenced by its body size, body condition, nutritive condition, disease, metabolism, excretion, age and sex (Aguilar et al., 1999). Furthermore, it is an indication of the conditions it experienced in early life: contaminant levels in its mother, the duration of nursing, birth order and the length of the calving interval preceding its birth (Hickie et al., 1999; Hickie et al., 2000; Ross et al., 2000; Ylitalo et al., 2001; Hickie et al., 2007). Females, through mobilization of lipid-associated toxins from the blubber during periods of high energy requirements, transfer toxic compounds to their offspring during gestation (via the placenta) and lactation (via their lipid rich-milk), resulting in a high exposure of newborns to those chemicals (O'Hara and O'Shea, 2005). In contrast, male cetaceans become increasingly contaminated as they grown older. In free ranging bottlenose dolphins (Tursiops truncatus), concentrations of OCs declined with female reproductive activity: blubber OC concentrations of nulliparous females were significantly greater than those of primiparous and multiparous females (Wells et al., 2005). In this species, approx. $80 \%$ of OCs are transferred to first born calves during the first seven weeks of lactation (Cockcroft et al., 1989). In captive T. truncatus, $\sum$ PCB was more than 2.5 times higher and $\sum D D T$ was three times higher in females whose calves died compared with females whose calves survived beyond six months (Reddy et al., 2001).

Reproductive failure in female harbour seals (Phoca vitulina) has been connected to feeding on contaminated fish. Average pup production per female harbour seal in the Dutch Wadden Sea population declined by approximately $30 \%$, and toxicology studies revealed that, of all the OCs analysed, PCB levels were significantly higher (by 5 to 7 times) in the Dutch Wadden Sea population compared to other contiguous populations (Reijnders, 1980). Experimental studies revealed that seals fed on fish from the Wadden Sea showed a decreased reproductive rate at an average total-PCB level of 25-27 $\mu \mathrm{g} \mathrm{g}^{-1}$ lipid, whereas a control group showed normal reproductive rates at 
mean PCB levels of 5-11 $\mu \mathrm{g} \mathrm{g}^{-1}$ lipid (Reijnders, 1986). Hormone profiles of non-pregnant animals fed fish from the Wadden Sea indicated that the effects occurred at the stage of implantation, whereas the follicular, luteal and post-implantation phases were not affected. On the whole, oestradiol-17 $\beta$ levels in seals fed with fish of a higher contaminant burden were lower than those of the control group. Lower levels of oestradiol could have impaired endometrial receptivity and prevented successful implantation of the blastocyst (Reijnders, 2003).

Piscivorous (and carnivorous) marine mammals inhabiting the mid-latitudes of Europe and North America are reported to have the highest PCB and DDT burdens (Aguilar et al., 2002). These findings are consistent with those previously reported on the geographical distribution of OCs in the atmosphere and surface waters, and are related to the extensive production and use of OCs in industrialized countries (Aguilar et al., 2002, and references therein). Common dolphins (Delphinus delphis) and harbour porpoises (Phocoena phocoena) are the two most abundant top predators in the eastern North Atlantic (ENA). Harbour porpoises are found predominately on the continental shelf, including the North and Baltic Seas. A single continuous population, with significant isolation by distance (i.e. the greater the distance the smaller the genetic correlation), has been reported ranging from waters off France, northward to Norway, (Fontaine et al., 2007). Separate sub-populations have been proposed within this region (Walton, 1997; Andersen et al., 2001; Andersen, 2003; Evans et al., 2009). One common dolphin population with low genetic differentiation has been reported to inhabit both the continental shelf (it is rarely reported in the North Sea) and adjacent oceanic waters, ranging from Portugal to Scotland (Murphy et al., 2009a, and references therein). The D. delphis population exhibits seasonal movements, possibly due to the migratory pattern of its preferred prey species (ICES WGMME, 2005).

Due to a decline in abundance and high bycatch rates, the harbour porpoise has been included on OSPAR's (The Convention for the Protection of the Marine Environment of the Northeast Atlantic, (www.ospar.org). "list of threatened and/or declining species and habitats" in Regions II (the greater North Sea) and III (the Celtic Sea, and waters off the west coast of Ireland and the UK). Both D. delphis and P. phocoena are listed under Annex IV of the EU Habitats Directive, and are afforded protection as European Protected Species (EPS). For any EPS, it an offence to deliberately or recklessly kill, capture, injure or disturb any such animal. It also requires the establishment of a system to monitor incidental capture and killing of individuals and to take measures to ensure that these activities do not have significant negative impacts on the species concerned. The harbour porpoise is also listed as an Annex II species in the EU Habitats Directive, which requires the establishment of Special Areas of Conservation (SAC). Signatory countries to ASCOBANS (Agreement on the Conservation of Small Cetaceans of the Baltic, North East Atlantic, Irish and North Seas) are required to assess the status and seasonal movements of the populations and stocks for the harbour porpoise and common dolphin; locate areas of special importance to their survival; identify present and potential threats to the different species; and establish efficient systems for reporting and retrieving bycaught and stranded specimens, in order to carry out full autopsies for collecting tissues for further studies, and reveal possible causes of death and to document food composition.

Although both $P$. phocoena and D. delphis have been found to consume similar prey species, for example Trisopterus spp., sandeels (Ammodytidae), herring (Clupea harengus), hake (Merluccius merluccius) and whiting (Merlangius merlangus) (Santos et al., 2004, MS 2004a, b), there are a number of population level differences between the species, including seasonal variations in diet and a number of life history traits. In UK waters, female $P$. phocoena attain sexual maturity at $c a 4.5$ years and the calving interval is ca 2 years (Learmonth et al., MS 2004; Murphy, MS 2008) compared to 8.2 years and 3.8 years, respectively, in D. delphis (Murphy et al., 2009b). A low pregnancy rate of $26 \%$ has been reported for the ENA $D$. delphis population, and although it has been suggested that the pregnancy rate may well in fact be the natural rate for this species in a temperate region, it cannot be ruled out that environmental and other anthropogenic activities, such as chemical and physical pollutants, may be contributing factors to the low reproductive output (Murphy et al., 2009b). Further, P. phocoena in UK waters exhibit among the lowest pregnancy rates reported for this species; ranging from $34 \%$ in Scottish waters (J. Learmonth, pers. comm.), $36 \%$ in western UK waters (English Channel, Irish and Celtic Seas) to $60 \%$ in the English North Sea (Murphy, MS 2008). This is in stark contrast to pregnancy rates of $95 \%$ for the Gulf of Maine and Bay of Fundy in the western North Atlantic (Read \& Hohn, 1995; data obtained between 1990 and 1993), 98\% for Icelandic waters (Ólafsdóttir et al., 2003), and 73\% for Danish waters (Sørensen \& Kinze, 1994). However, a lower pregnancy rate of $59 \%$ has been observed in Dutch waters (M. Addink, T.B. Sørensen, M. Garc1'a Hartmann, H. Kremer, unpublished data on 27 mature females during 1988-1995) and J. Learmonth (pers. comm.) point out that the high proportion of animals in the Scottish sample that had died from pathological causes may have resulted in the pregnancy rate being underestimated.

The EC-funded BIOCET (BIOaccumulation of persistent organic pollutants in small CETaceans in 
European waters: transport pathways and impact on reproduction) project analysed samples from female D. delphis and P. phocoena that stranded along coastlines in the ENA. Results on geographic variation in POP burdens, and relationships between POP burdens and age, fatty acid profiles, health status and reproduction, were presented in Pierce et al. (2008). The most important variable explaining POP profiles in common dolphin blubber was individual feeding history, while those in porpoises were more strongly related to individual condition. A substantial proportion of individuals in the BIOCET sample had contaminant levels above a threshold PCB level that has been reported to have adverse health effects. The threshold in question is $17 \mu \mathrm{g} \mathrm{g}^{-1}$ PCB lipid weight, which was derived by Kannan et al. (2000) and is based on experimental studies of both immunological and reproductive effects in seals, otters, and mink. This threshold was frequently exceeded in both $P$. phocoena (47\% of individuals) and D. delphis (40\%), especially P. phocoena from the southern North Sea (74\%) and D. delphis inhabiting waters off the French coast (50\%). Within the $D$. delphis sample, the incidence of pregnancy was negatively related to contaminant burdens. However, this relationship did not conclusively demonstrate that high POP concentrations inhibit pregnancy in this species since, for example, infertility may allow high levels of POPs to bioaccumulate (Pierce et al., 2008). The analysis of effects of POPs on reproduction in Pierce et al. (2008) was restricted to consideration of pregnancy rates. However, additional information on reproductive status is available from examination of ovarian scars.

In order to further investigate the effects of POPs on reproduction in both these species, contaminant levels have to be assessed against an index of reproductive activity. It has been reported that corpora albicantia (ovarian scars of ovulation and pregnancy) persist throughout the life of some marine mammals, as a consequence of the large amount of connective tissue present and poor vascularisation (Stewart and Stewart, 2003) and therefore provide an index of the number of past ovulations (Perrin and Donovan, 1984), i.e. complete reproductive activity. However, contrasting results have highlighted inconsistencies with this theory. In some small delphinids, it has been proposed that CAs of infertile ovulations are more likely to be resorbed than those of pregnancy, which has been suggested in young mature female bottlenose dolphins (Harrison et al., 1972; Perrin and Reilly, 1984, and references therein). Whereas, the ovaries of senescent female Stenella spp. are withered with fewer CAs present compared to ovaries of younger females, suggesting that some CAs may eventually be resorbed (Perrin and Reilly, 1984, and references therein). More recent studies by Brook et al. (2002) and Dabin et al. (2008) have further questioned the assumptions of CA persistence in the ovaries of small delphinids.

Marine mammals provide information on the chemicals which present the greatest risk to consumers at the top of the food chain, something that cannot be adequately described or predicted in laboratory models (Ross, 2000). Therefore, the current study will focus on two cetacean species that feed on commercially important fish species in the ENA, the common dolphin and harbour porpoise, incorporating data produced by the EC-funded $5^{\text {th }}$ Framework BIOCET project and data from a control group study which was funded in-part by the UK Department of the Environment, Food and Rural Affairs (Defra) Marine Research Program and also by ASCOBANS. In order to assess the possible long-term effects of POPs on the continued viability of these populations, we investigated the impact of POPs on reproductive activity in females. Initially, investigations were undertaken to assess the significance, in terms of our understanding of individual reproductive history, of corpora albicantia in the ovaries of D. delphis and $P$. phocoena. The relationship between accumulation of corpora scars and contaminant burdens was examined, taking into account the health status of the individual. Further, variations in contaminant burdens were assessed between mature females in different reproductive states (resting mature, pregnant and lactating) and, between nulliparous, primiparous and multiparous females. Finally, we investigated whether increased contaminant burdens inhibit ovulation or pregnancy.

The research undertaken in the current study has important implications for the conservation of both these species in the ENA. If the results identify that contaminants have an adverse effect on individual reproductive capabilities, the species would be more vulnerable to exploitation than is normally assumed, especially from other anthropogenic activities such as incidental capture, and would not necessarily recover from exploitation in a predictable way.

\section{Methods}

\section{Sampling programme}

In all cases, data collection protocols followed European Cetacean Society guidelines for gross postmortem examination and tissue sampling (Kuiken and Garcia Hartmann, 1991). Phase one analysed samples collected by the EC-funded BIOCET project, which included partners from a number of European national marine mammal strandings schemes. Stranded P. phocoena and D. delphis were sampled between 2001 
and 2003 (see Pierce et al. (2008) for further information and distribution maps), and ranged in decomposition states from fresh (CC2) to moderately decomposed (CC3) (Kuiken and Garcia Hartmann, 1991). Females recovered in fresh condition, from which all necessary samples could be obtained, were prioritised for contaminant analysis; resulting in sample sizes of $70 \mathrm{D}$. delphis obtained from Ireland, France and Spain and 67 P. phocoena from Ireland, Scotland, southern North Sea (The Netherlands, Belgium, France and three immature females from Galicia) - the three immature animals are included in the 67 porpoises. Due to funding constraints, health status and cause of death were not determined for all individuals with estimated body burdens of contaminants and therefore these variables were not included in the statistical analysis. Data and samples for assessing reproductive status, such as gonads and teeth, were collected from all stranded females, when possible, throughout the sampling period of the project; resulting in sample sizes of $177 \mathrm{D}$. delphis and $99 P$. phocoena. The D. delphis samples obtained from France included those originating from a mass live stranding event that occurred in February 2002 at Pleubian, Brittany. The group comprised adult $(7+$ years old) females accompanied by their unweaned calves. Of the 53 individuals found dead, 52 were fully necropsied (Dabin et al., 2008; Viricel et al., 2008), and reproductive data from 49 females were available for the current study. In a previous paper, Dabin et al. (2008) assessed the use of ovarian scars to reconstruct individual reproductive histories. Their analysis included data from the Pleubian mass live stranding event.

In order to account for the effects of health status and cause of death in the analysis, a follow-up control group study was undertaken during phase two. 43 female D. delphis taken incidentally as bycatch in fishing gear, and which subsequently stranded along the UK coastline, were designated as the control group. Cause of death was determined during detailed post-mortem examinations carried out by the UK Defra-funded Cetacean Strandings Investigation Programme (CSIP; Jepson et al., 2005). Individuals stranded between 1992 and 2004, and the majority were found along the southwest coast of the UK (95\%), between December and March (88\%). Pathological investigations, including gross examination and histological, bacteriological and/or virological analyses, identified whether dolphins were suffering from any infectious or non-infectious diseases that might inhibit reproduction (Jepson, 2005). The control group sample was divided into three health status categories: Category 1 - healthy individuals; Category 2 - health of individuals mildly compromised (but may still be capable of successfully reproducing); and Category 3 - individuals suffering from severe (and potentially fatal) infectious or non-infectious disease. $93 \%$ of the sample was assessed as Category 1 (Table 1). Furthermore, where nutritional information was available $(n=40), 82 \%$ were classified in good and $15 \%$ in moderate condition, and only one individual was in poor nutritional condition $(3 \%)$.

Basic data collected from each animal included stranding location, date, species, sex, total length and blubber thickness (measured immediately in front of the dorsal fin in dorsal, midline and ventral positions). Between 90 and $95 \%$ of the total body burden of many POPs, particularly PCBs and DDTs, is found in the blubber because of its high lipid content (Aguilar, 1985). Blubber samples for POP analysis were taken from the left side in front of the dorsal fin. Samples were complete vertical cross-sections to prevent any possible effects of lamination of the blubber, and were stored frozen at $-20^{\circ} \mathrm{C}$. During transport, samples were packed in insulation boxes with dry ice to ensure that they remained frozen.

Teeth $(n \geq 5)$ were collected from each sampled individual, selecting the least worn/damaged and least

Table 1. Percentage of D. delphis $(n=43)$ in three health status categories in the control group study. Category 1 - healthy individuals; Category 2 - health of individuals only mildly compromised. Category 3 - individuals suffering from severe infectious or non-infectious disease.

\begin{tabular}{lcccc}
\hline & $\begin{array}{c}\text { Sample size } \\
n\end{array}$ & $\begin{array}{c}\text { Cat. 1 } \\
\%\end{array}$ & $\begin{array}{c}\text { Cat. 2 } \\
\%\end{array}$ & $\begin{array}{c}\text { Cat. 3 } \\
\%\end{array}$ \\
\hline Immature & 20 & 95 & 5 & 0 \\
Lactating & 7 & 100 & 0 & 0 \\
Pregnant & 3 & 100 & 0 & 0 \\
Pregnant \& Lactating & 2 & 100 & 0 & 0 \\
Resting Mature & 11 & 82 & 18 & 0 \\
\hline
\end{tabular}


curved teeth, to ensure sufficient material for replicate preparations. Teeth were preserved frozen or in $70 \%$ alcohol. The uterus was examined for presence of a foetus, and the ovaries were collected and preserved in $10 \%$ neutral buffered formalin. Milk glands were examined for evidence of lactation by cutting through the mammary glands, and noting if milk or colostrum was present in the sinuses.

\section{POP measurements}

For the BIOCET data, analysis of POP concentrations in cetaceans was carried out at the Royal Netherlands Institute for Sea Research (NIOZ), with some Scottish harbour porpoise samples analysed at the UK Centre for Environment, Fisheries and Aquaculture Science (Cefas). For information on the methodologies used in determining POP concentrations, and comparisons between laboratories, see Pierce $\geq$. (2008). Eighteen PCB congeners were selected for analysis within the BIOCET project (CB28, CB49, CB52, CB99, CB101, CB118, CB128, CB138; CB141, CB149, CB151, CB153, CB170, CB177, CB180, CB183, CB187 and CB194). Data available from Cefas (for Scottish porpoises) excluded values for CB99 and CB177, which were therefore dropped from the majority of the analyses using porpoise data. Other chemicals analysed were $p, p$ '-DDE, which is the most persistent metabolite and the major representative of the insecticide DDT-group, and brominated flame retardants such as brominated diphenyl ethers (PBDE congeners: BDE47, BDE99, BDE100, BDE153 and BDE154) and hexabromocyclododecane (HBCD isomers: $\alpha, \beta$, and $\gamma$ ) - the principal brominated flame retardant in polystyrene foams used in the building industry. Due to funding constraints, data on HBCD concentrations were only available for $44 \mathrm{P}$. phocoena and $60 \mathrm{D}$. delphis, whereas for other POPs the sample size increased to 67 and 70 , respectively. For the $D$. delphis control group study $(n=43)$, the sixteen selected PCB congeners and $p, p$ '-DDE were analysed by Cefas.

As mentioned previously, a $\Sigma$-PCB level of $17 \mu \mathrm{g} \mathrm{g}^{-1}$ lipid has been reported as a threshold level for adverse health effects in marine mammals (Kannan et al., 2000; Schwacke et al., 2002). For comparison with this figure, which was based on the commercial PCB mixture Aroclor 1254, we also derived the "ICES7" value (the sum of concentrations of CB28, CB52, CB101, CB118, CB138, $\mathrm{CB} 153, \mathrm{CB} 180$ ), since three times this value is equivalent to the Aroclor 1254 value (Jepson et al., 2005). Using thresholds in this way warrants caution owing to possible differences in species sensitivities; however, as in Jepson et al. (2005), it is proposed that this threshold blubber concentration for adverse health effects should provide a benchmark for interpreting whether associations between reproductive activity and $\mathrm{PCB}$ exposure are biologically significant.

\section{Determination of age and reproductive status}

All teeth and gonadal material obtained during the BIOCET project were analysed, irrespective of whether contaminant burdens were not investigated. Where data were available, teeth and gonadal samples from the control group were also analysed. Age was determined by analysing growth layer groups (GLGs) in the dentine of teeth, following Lockyer (1995). The most central and complete sections (including the whole pulp cavity) were selected from each tooth, stained, mounted on glass slides, and allowed to dry. GLGs were counted under a binocular microscope and on enhanced computer images of the sections. All readings were initially made blind (with no access to other data on the animals) and replicate counts were made by at least two readers, usually from separate labs. In cases where there was disagreement, teeth were re-examined by readers and an age and/or an age range was agreed. As ages were recorded by a number of different researchers, cross-calibration exercises were carried out for further information see Rogan et al. (MS 2004).

Before examination, the preserved ovaries were rinsed in water for 24 hours and then replaced in their containers with $70 \%$ ethanol. For each ovary, the maximum length, height, width (mm) and weight (g) were recorded. Corpora scars present on the ovary were classified into corpora lutea, regressing corpora lutea, and corpora albicantia. The corpus luteum (CL) is an endocrine gland and is easily recognisable on the ovary as a pronounced distension, usually yellow in colour as a result of the yellow pigments of the carotenoid luteins. A regressing CL has been defined as a luteal structure that has started to regress, and appears faintly yellowish in gross observation. A regressing corpus luteum CL eventually gives rise to a tissue scar called a corpus albicans. A corpus albicans (CA) can appear as a spherical knob or as raised, wrinkled scar and it is easily recognisable on the cut surface as a pale fibrotic area. CAs are composed of white connective tissue that becomes fragmented with age. Ovaries were hand-sectioned into $0.5-2 \mathrm{~mm}$ slices and examined internally under a binocular microscope for the presence of additional corpora scars. Females were considered sexually mature if the ovaries contained at least one corpus luteum or albicans. Pregnancy was established by the presence of an embryo/foetus due to the difficulty, during gross and histological examinations, in distinguishing a CL of pregnancy from a CL of ovulation. Females were classified 
into five reproductive states: immature, pregnant, pregnant $\&$ lactating, lactating, and resting mature (not pregnant or lactating). For the BIOCET dataset an additional category "pathological" was included, based on gross (and occasionally histological) examination of abnormalities of the reproductive system; i.e. ovarian cysts, uterine bodies, mastitis, and early mammary gland development and lactation in immature individuals.

\section{Data analysis}

For the BIOCET dataset, generalised linear models (GLM) and generalised additive models (GAM) were used to model individual variation in numbers of CAs in relation to a series of explanatory variables, namely reproductive status (pregnancy), average CA size, geographic location (region), age, POP concentrations and condition (proxied by dorsal blubber thickness) for both $D$. delphis and $P$. phocoena. Seasonality was not taken into account within the analysis due to sampling biases in the strandings data, as the majority of individuals stranded during the first quarter (Jan-Mar). In principle, CA numbers are expected to follow a Poisson distribution but models were checked for over-dispersion of the response variable, and a quasi-Poisson distribution was used when slight over-dispersion as detected. Average CA size (mean length of CAs on the left ovary) was modelled as a function of age and the number of CAs present, using GAM, in this case assuming a Gaussian distribution. For analysis of geographical variation, BIOCET samples were grouped into five regions: Scotland, Ireland, southern North Sea (Netherlands, Belgium and the French coast north of Calais), France (Biscay coast of France) and Galicia. Concentrations of PBDEs and HBCDs in harbour porpoise were log-transformed due to their highly skewed distributions.

The advantage of GAM over other regressiontype models is that it is not necessary to assume linear relationships between response and explanatory variables. Non-linear relationships are captured as "smoothers" (Hastie and Tibshirani, 1990; Zuur et al., 2007). However, if all relationships prove to be approximately linear, GLM can then be used instead. When fitting smoothers, the maximum complexity of the resulting curve can be constrained by setting an upper limit to the number of "knots". We used a maximum value of four to avoid overfitting, i.e. to avoid the fitting of unrealistically complex relationships. Explanatory variables to be retained in the final model were selected using a combination of forwards and backwards selection. Several alternative methods are available to evaluate goodness of fit and thus select the best model. We selected the model with the lowest value for the Akaike Information Criterion (AIC), in which all remaining explanatory variables have significant effects (as determined by $F$, $t$ or $\chi^{-2}$ tests, depending on the distribution assumed for the response variable and whether the explanatory variable was assumed to have a linear effect or not), and there are no obvious patterns in the residuals. Where an explanatory variable was marginally significant ( $p \sim 0.05$ ), an $F$ test was used to compare models with and without the variable in question and if the difference was not significant, the simpler model was accepted (Zuur et al., 2007). All GAMs were fitted using BRODGAR 2.6.5. (www.brodgar.com), an interface for the $\mathrm{R}$ statistical programming language. Additional comparisons of CA numbers were carried out using the Mann-Whitney test.

\section{Results}

\section{Phocoena phocoena - BIOCET sample}

Reproductive status was determined for 99 female harbour porpoises from European waters, of which $62 \%$ were immature. Three Dutch female $P$. phocoena were classed as pathological, based on milk gland pathology. Two of these individuals would have been described as mature based on age, body length and development of mammary gland tissue, but no corpora scars were present on the ovaries. Of the 38 mature females, 11 were pregnant, two were pregnant and lactating, 6 were lactating, 15 were classed as resting mature and 4 as pathological. Resting mature female $P$. phocoena had the highest average number of corpora scars (average $=7.8$ scars, range $1-16, n=15$ ), followed by lactating (average $=7.5$, range $3-11, n=6$ ) and pregnant females (average $=4.7$, range $1-17, n=10)$. However, no significant variation in number of corpora scars (Corpora albicantia and lutea) was observed between these three reproductive groups (Mann-Whitney test, $p>0.05$ ).

\section{Delphinus delphis- BIOCET sample}

Reproductive status was determined for 177 female common dolphins, of which 103 (58\%) were sexually mature (Table 2). Of the 103 mature females, 22 were pregnant, 9 were pregnant and lactating, 13 were lactating, 54 were resting mature and 5 were classified as pathological. Resting mature female D. delphis had the highest average number of corpora scars (average $=17.8$, range $=2-34, n=40$ ), followed by pathological (average 16.2, range $3-26, n=5$ ) and lactating (average $=15.5$, range $2-26, n=12$ ) females. Pregnant (average $=9.4$, range $=1-23, n=20$ ) and pregnant $\&$ lactating (average $=9.7$, range $=2-19, \mathrm{n}=9$ ) females had the lowest average number of corpora scars. Resting mature female $D$. delphis had a significantly higher 
Table 2. Reproductive data from P. Phocoena $(n=99)$ and D. delphis $(n=177)$ in the BIOCET study and the $D$. delphis control group study $(n=43)$.

\begin{tabular}{|c|c|c|c|c|c|}
\hline & $\begin{array}{l}\text { Body } \\
\text { Length } \\
\text { (cm) }\end{array}$ & $\begin{array}{l}\text { Age } \\
\text { (yrs) }\end{array}$ & $\begin{array}{l}\text { Combined } \\
\text { gonadal } \\
\text { weight }(\mathrm{g})\end{array}$ & $\begin{array}{c}\text { No. of } \\
\text { corpora } \\
\text { scars }{ }^{1}\end{array}$ & $\begin{array}{l}\text { Average no. } \\
\text { of corpora } \\
\text { scars (SE) }\end{array}$ \\
\hline $\begin{array}{l}\text { Immature BIOCET } \\
P . \text { phocoena }\end{array}$ & $\begin{array}{r}66-143 \\
(n=59)\end{array}$ & $\begin{array}{r}0-4.5 \\
(n=59)\end{array}$ & $\begin{array}{r}0.3-3.2 \\
(n=51)\end{array}$ & 0 & 0 \\
\hline $\begin{array}{l}\text { Mature BIOCET } \\
\text { P. phocoena }{ }^{2}\end{array}$ & $\begin{array}{l}139-192 \\
(n=36)\end{array}$ & $\begin{array}{r}3.5-24 \\
(n=32)\end{array}$ & $\begin{array}{l}1.4-20.7 \\
(n=32)\end{array}$ & $\begin{array}{r}1-17 \\
(n=34)\end{array}$ & $\begin{array}{r}6.9 \\
(0.88)\end{array}$ \\
\hline $\begin{array}{l}\text { All BIOCET } \\
P . \text { phocoena } \text { data }^{2}\end{array}$ & $\begin{array}{r}66-192 \\
(n=95)\end{array}$ & $\begin{array}{r}0-24 \\
(n=91)\end{array}$ & $\begin{array}{l}0.3-20.7 \\
(n=83)\end{array}$ & $\begin{array}{r}1-17 \\
(n=34)\end{array}$ & $\begin{array}{r}6.9 \\
(0.88)\end{array}$ \\
\hline $\begin{array}{l}\text { Immature BIOCET } \\
\text { D. delphis }\end{array}$ & $\begin{array}{r}91-206 \\
(n=74)\end{array}$ & $\begin{array}{r}0-10 \\
(n=71)\end{array}$ & $\begin{array}{r}0.3-7.5 \\
(n=50)\end{array}$ & 0 & 0 \\
\hline $\begin{array}{l}\text { Mature BIOCET } \\
\text { D. delphis }\end{array}$ & $\begin{array}{r}170-220 \\
(n=102)\end{array}$ & $\begin{array}{r}6-26 \\
(n=96)\end{array}$ & $\begin{array}{r}1.7-25.3 \\
(n=89)\end{array}$ & $\begin{array}{r}1-34 \\
(n=86)\end{array}$ & $\begin{array}{r}14.6 \\
(0.87)\end{array}$ \\
\hline $\begin{array}{l}\text { All BIOCET } \\
\text { D. delphis data }\end{array}$ & $\begin{array}{r}91-220 \\
(n=176)\end{array}$ & $\begin{array}{r}0-26 \\
(n=167)\end{array}$ & $\begin{array}{r}0.3-25.3 \\
(n=139)\end{array}$ & $\begin{array}{r}1-34 \\
(n=86)\end{array}$ & $\begin{array}{r}14.6 \\
(0.87)\end{array}$ \\
\hline $\begin{array}{l}\text { Immature control } \\
\text { D. delphis }\end{array}$ & $\begin{array}{l}107-210 \\
(n=20)\end{array}$ & $\begin{array}{r}0-11 \\
(n=19)\end{array}$ & $\begin{array}{r}0.76-5.46 \\
(n=16)\end{array}$ & 0 & 0 \\
\hline $\begin{array}{l}\text { Mature control } \\
\text { D. delphis }\end{array}$ & $\begin{array}{l}186-221 \\
(n=22)\end{array}$ & $\begin{array}{r}7.5-30 \\
(n=19)\end{array}$ & $\begin{array}{r}1.88-17.48 \\
(n=22)\end{array}$ & $\begin{array}{r}1-16 \\
(n=23)\end{array}$ & $\begin{array}{r}7.2 \\
(1.16)\end{array}$ \\
\hline $\begin{array}{l}\text { All control } \\
\text { D. delphis data }\end{array}$ & $\begin{array}{l}107-221 \\
(n=42)\end{array}$ & $\begin{array}{r}0-30 \\
(n=38)\end{array}$ & $\begin{array}{r}0.76-17.48 \\
(n=38)\end{array}$ & $\begin{array}{r}1-16 \\
(n=23)\end{array}$ & $\begin{array}{r}7.2 \\
(1.16)\end{array}$ \\
\hline
\end{tabular}

${ }^{1}$ Including corpora lutea and corpora albicantia

${ }^{2}$ Excluding two "pathological" harbour porpoises reported as mature based on milk gland pathology

number of corpora scars than pregnant (Mann-Whitney test, $p=0.0003, n=60$ ) and pregnant $\&$ lactating females (Mann-Whitney test, $p=0.0043, n=49$ ); $88 \%$ of the resting mature sample had $\geq 10$ corpora scars. Further, lactating females had a significant higher number of corpora scars than pregnant females (Mann-Whitney test, $p=0.0493, n=32$ ).

\section{Size and number of corpora albicantia - BIOCET sample}

Corpora albicantia (CA) were recorded on both ovaries in $D$. delphis, although very few scars were observed on the right ovary in P. phocoena (Fig. 1). In $P$. phocoena, average CA size was independent of the number of corpora albicantia present, though the sample size was small $(n=19)$, and there was also no significant relationship with age. In $D$. delphis, the model for average CA size explained $41.4 \%$ of deviance $(n=71)$ and included strong effects of age (an asymptotic curve, with a positive effect of age up to around age 15, estimated degrees of freedom $=2.01, F=5.236, p=0.0077$ ), and total number of corpora albicantia (negative, edf =
$1.49, F=29.167, p<0.0001)$. Overall, average CA size decreased with increasing number of corpora albicantia due to an increase in the number of smaller CAs present on the ovaries. There was no significant correlation between the number of corpora scars and age for sexually mature P. phocoena $\left(r^{2}=0.004, p=0.735, n=32\right.$; Fig. $\left.2 \mathrm{a}\right)$ or D. delphis ( $r^{2}=0.036, p=0.094, n=79$; Fig. 2b).

A GAM fitted to data on both immature and mature porpoises, testing for effects of age, condition, region and pregnancy indicated that the number of CAs in porpoise ovaries was significantly related to age, condition and region. This model, which assumed a quasi-Poisson distribution for the response variable, explained $70.8 \%$ of deviance. The age effect (edf $=2.83, F=13.89$, $p<0.0001, n=88$; Fig. 3a) unsurprisingly reveals an increase in CA numbers up to an age of around 5 (soon after attainment of sexual maturity), while the effect of blubber thickness (condition) was weakly negative (edf $=2.71, F=3.91, p=0.0147, n=81$; Fig. $3 b$ ). Irish porpoises had a higher number of CAs than Scottish porpoises $(t=2.050, p=0.0440)$. Although the overall effect of region was not significant $(F=3.915, p=0.0641)$, 

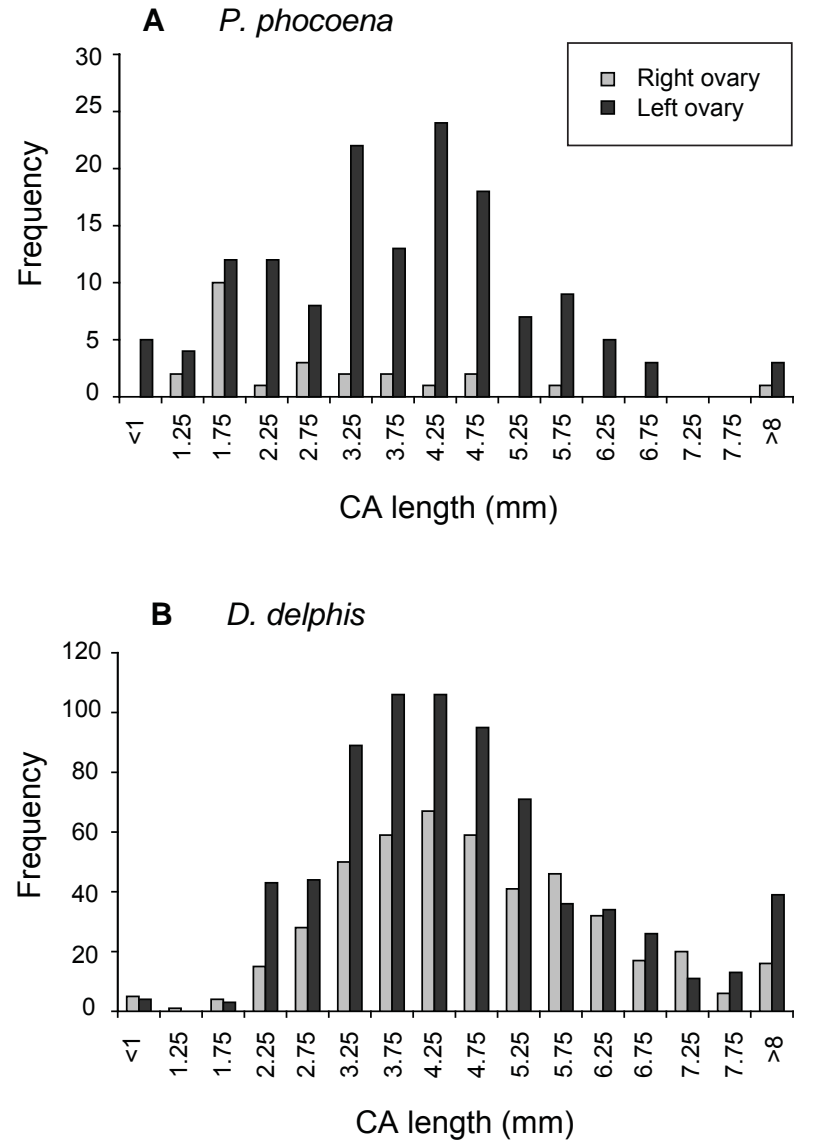

Fig. 1. Size distribution of corpora albicantia in (A) BIOCET P. phocoena (right ovary, $n=3$; left ovary, $n=21$ ), and (B) BIOCET D. delphis (right ovary, $n=63$; left ovary, $n=75$ ).

its inclusion significantly improved the final model $(F=2.887, p=0.0386)$. It should be noted that the data include one very old French animal (24 years of age) while the next oldest individual was 15 years old.

A (quasi-Poisson) GAM for the number of corpora albicantia in $D$. delphis ovaries in relation to age, pregnancy and region explained $72.8 \%$ of deviance. The number of CAs reaches an asymptote around age 12 (edf $=2.94, F=16.92, p<0.0001, n=123$; Fig. $3 c$ c) and fewer CAs were present in the ovaries of pregnant females $(F=23.11, p<0.0001)$. There was also regional variation $(F$ $=4.09, p=0.0085)$, with animals from Galicia having fewer CAs than animals from Scotland $(t=-2.81, p=0.0059)$. Blubber thickness data were missing for Galicia. If blubber thickness is included in the model (reducing sample size to 100 animals), effects of age and pregnancy remain, the regional difference disappears (presumably due to the absence of Galician data) and blubber thickness (condition) is seen to have an almost linear positive effect $(\mathrm{edf}=1.45$, $F=6.13, p=0.0074$; Fig. 3d).
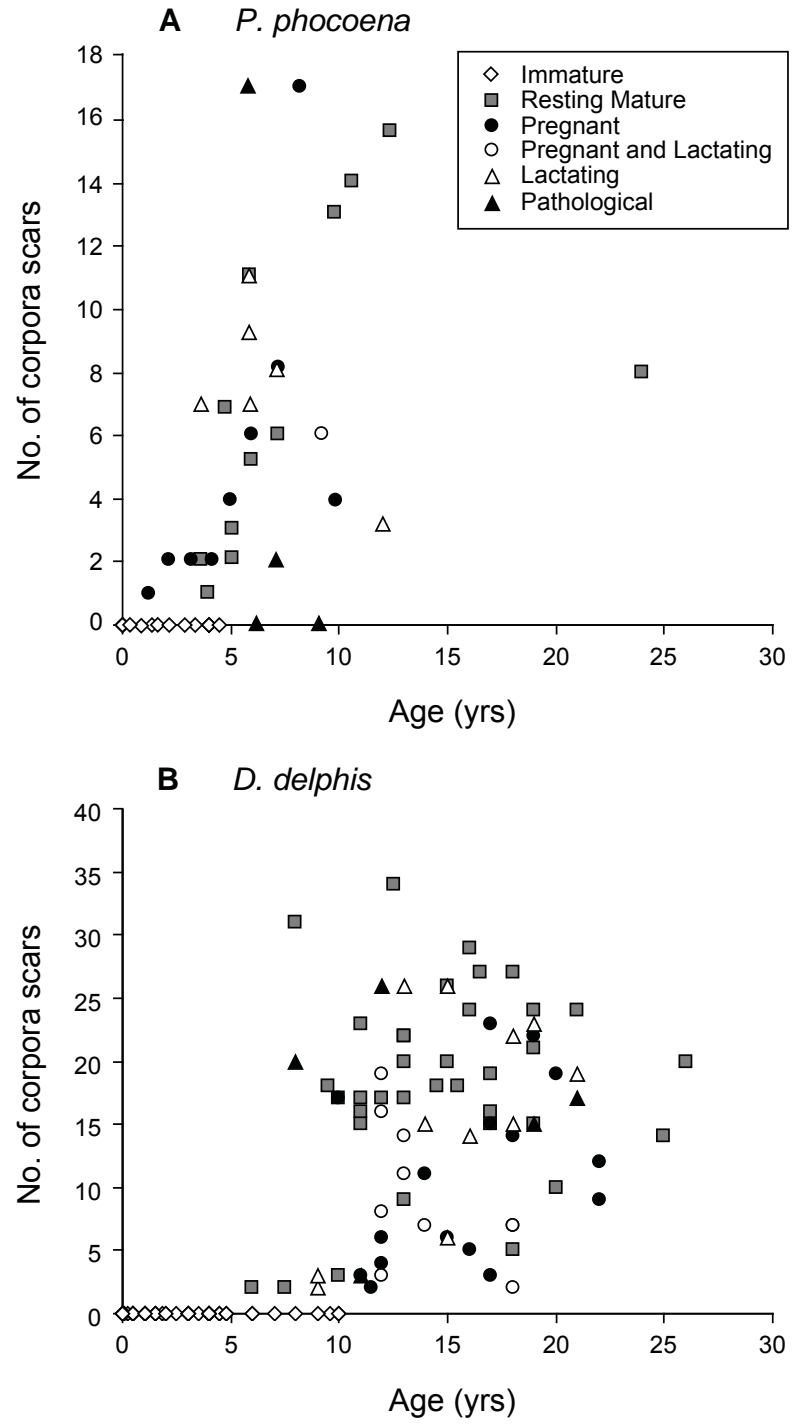

Fig. 2. The total number of corpora scars (corpora albicantia and corpora lutea) in small cetacean ovaries in the BIOCET sample as a function of age in (A) P. phocoena $(n=86)$, and (B) D. delphis $(n=124)$.

\section{Effects of POP on reproductive activity - BIOCET sample}

The GAM for the number of corpora albicantia on porpoise ovaries was improved by adding an effect of $\sum 16 \mathrm{PCB}$ congeners concentrations $(87.5 \%$ of deviance explained, $n=59$ ). As in the previous model, the number CAs rose to reach an asymptote around age 5 (edf $=3.00, F=9.05, p<0.0001$ ), decreased as blubber thickness increased (edf $=2.15, F=10.14, p=0.0001$ ) and showed significant regional variation $(F=7.04, p$ $=0.0020)$, with Irish animals having more CAs in their ovaries than Scottish animals $(t=3.31, p=0.0018)$. The number of CAs was lower at higher PCB concentrations 

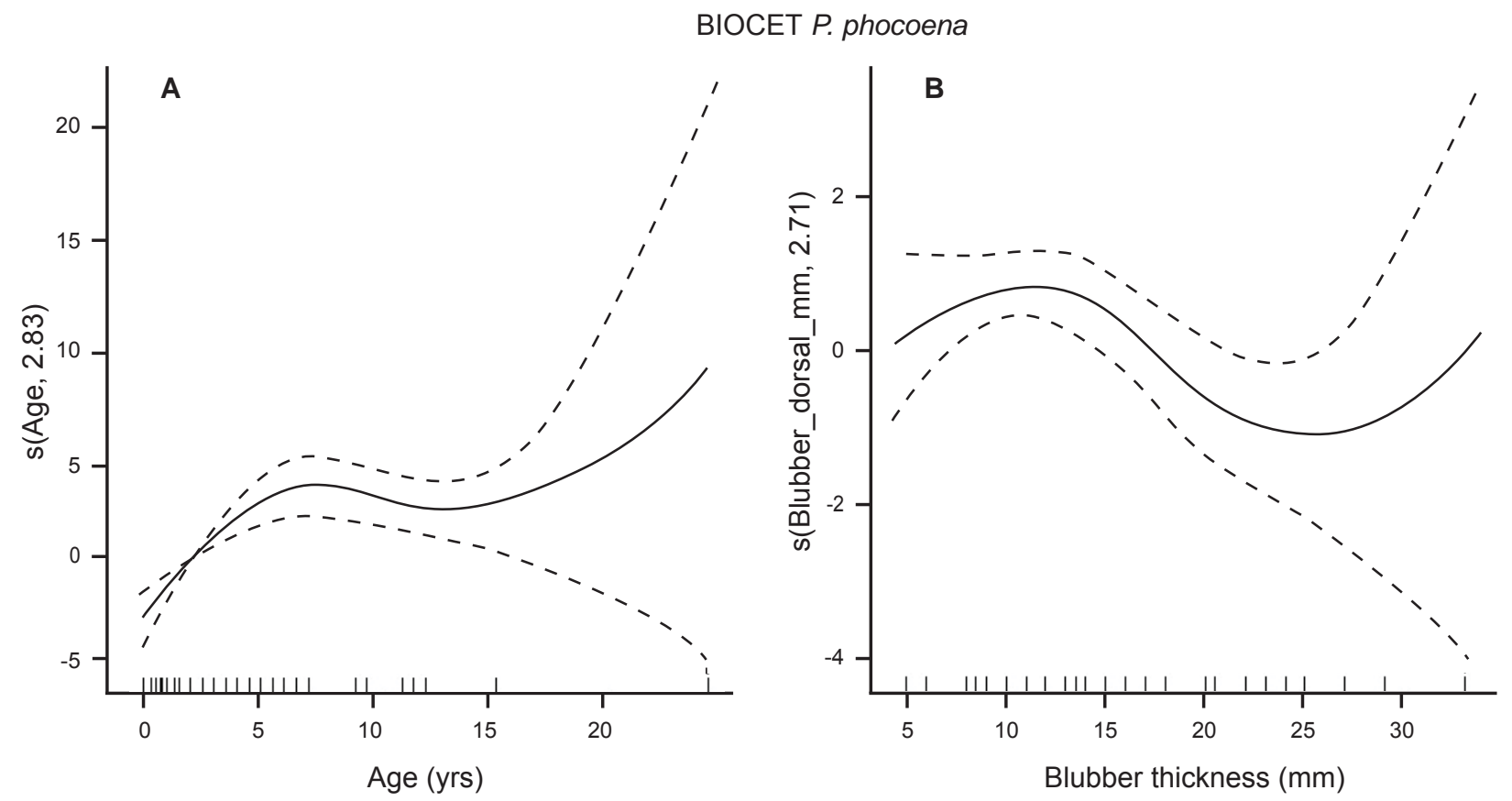

BIOCET D. delphis
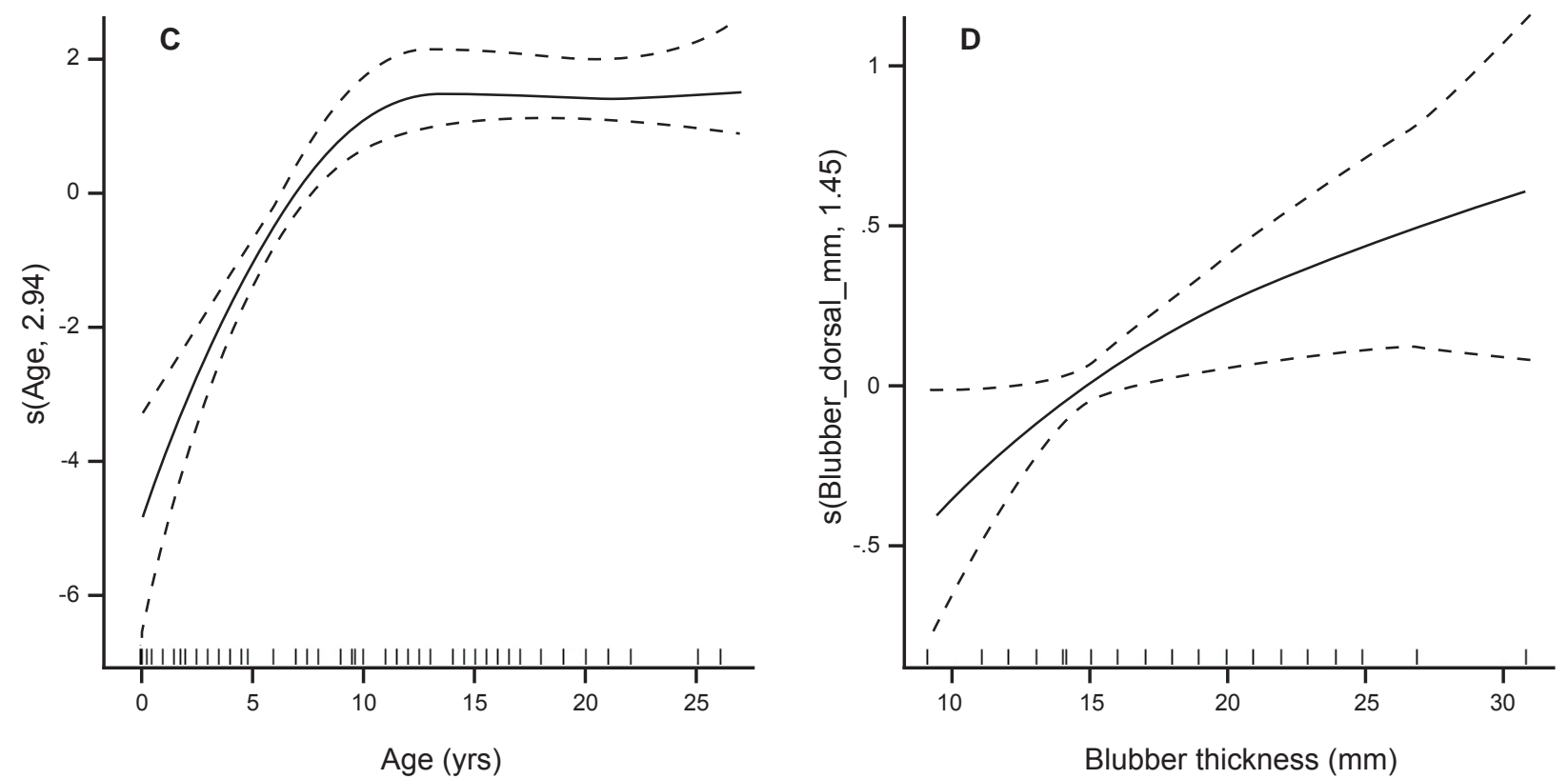

Fig. 3. Smoothers for partial effects of explanatory variables on total number of corpora albicantia: $(\mathbf{A})$ age $(n=88)$ and (B) dorsal blubber thickness $(n=81)$ in BIOCET P. phocoena, and (C) age $(n=123)$ and (D) dorsal blubber thickness $(n=100)$ in BIOCET D. delphis. In all cases, the $y$ axis represents the strength and direction of the effect of the explanatory variable. The axis label format indicates the estimated degrees of freedom (edf or "curviness") of the smoother. For example, s(Age, 2.96) indicates a smooth function of age with edf $=2.96$. 
(edf $=2.02, F=9.50, p=0.0003$, Fig. 4 a). Substituting PBDE concentrations for PCBs, no significant effect of PBDEs was found. However, a significant effect was seen for HBCDs, with fewer CAs present in animals with higher HBCD concentrations (edf $=1.36, F=4.80, p=$ 0.0266 ; Fig. 4b). It should be noted that this latter model contained effects of age and blubber thickness as before but no effect of region, and explained $80.7 \%$ of deviance $(n=36)$. A significant effect was also seen for DDE concentration (edf $=1.72, F=7.35, p=0.0026$; Fig. $4 c)$. In this model, effects of age and blubber thickness were again retained, and the previously seen regional difference was more pronounced $(F=5.41, p=0.0075)$. The model explained $85.5 \%$ of deviance $(n=59)$. Note that models in which the concentration of one category of POPs was included as a predictor were not improved by adding the concentration of a second category of POPs as an additional predictor.

The models for numbers of corpora albicantia in common dolphin ovaries (with or without blubber thickness included) were not improved by including PCB burden ( $\sum 18 \mathrm{PCB}$ congeners) as a predictor. Similarly, the models were not improved by including PBDE, HBCD or DDE concentrations as predictors.

\section{Threshold level - BIOCET sample}

No significant relationship between age and PCB burden [ $\left(\sum\right.$ 7ICES congeners $\left.) \cdot 3\right]$ was observed for either P. phocoena $\left(r^{2}=0.008, p=0.490, n=60\right)$ or $D$. delphis $\left(r^{2}=0.000, p=0.965, n=66\right)$. The highest PCB burden was reported in P. phocoena, with $120 \mu \mathrm{g} \mathrm{g}^{-1}$ lipid reported in individual, compared to a maximum of $84.54 \mu \mathrm{g} \mathrm{g}^{-1}$ lipid in D. delphis (Fig. 5). High concentrations were reported in immature P. phocoena, ranging from 1.93 to $60.9 \mu \mathrm{g} \mathrm{g}^{-1}$ lipid, of which $42 \%$ had contaminant loads above the threshold level of $17 \mu \mathrm{g} \mathrm{g}^{-1}$ lipid for adverse health effects. All pregnant $P$. phocoena sampled had contaminant loads below $20 \mu \mathrm{g} \mathrm{g}^{-1}$ lipid (Fig. 5a). A decline in contaminant load with increasing corpora number (Corpora albicantia and lutea) was observed, which was significant for resting mature females ( $p=0.010, n=9)$, though not for the whole sexually mature female $P$. phocoena sample ( $p=0.105, n=21$; excluding three "pathological" females). In contrast, a significant increase in corpora number and PCB burden was observed for sexually mature $D$. delphis $\left(r^{2}=0.1263, p=0.029, n=38\right.$; Fig. $\left.5 b\right)$. When the threshold level was applied to these data, resting mature females (not pregnant or lactating) composed $83 \%$ of the mature sample above this level. In general, $D$. delphis with high contaminant burdens above the threshold level for adverse health effects were resting mature females with high numbers of corpora scars.
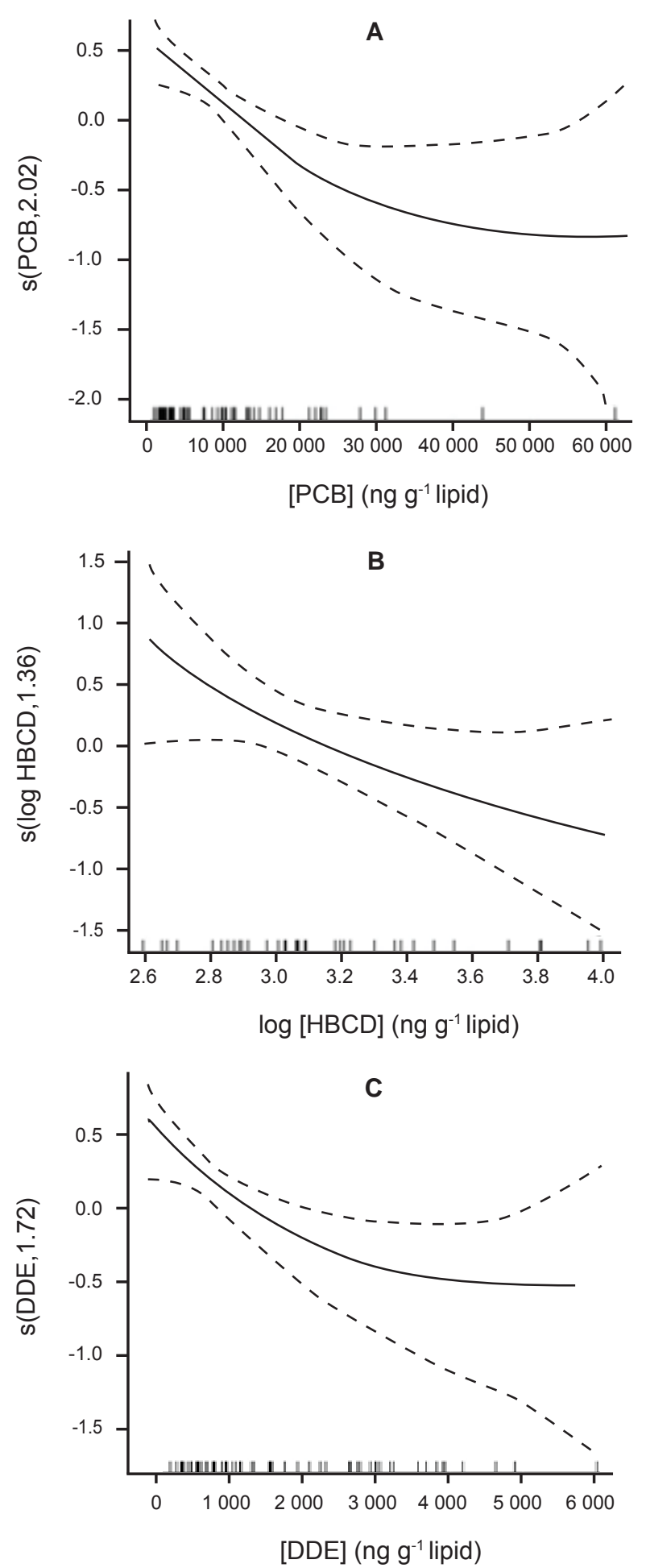

Fig. 4. Smoothers for partial effects of explanatory variables on total number of corpora albicantia in ovaries of BIOCET P. phocoena, for models which include age and blubber thickness (plus regional variation in the first model): partial effects of concentrations of (A) $\sum 16 \mathrm{PCB}$ congeners $(n=59)$, (B) HBCD isomers $(n=36)$, and (C) DDE $(n=59)$. 


\section{Threshold level - Control group sample}

In the control group of "healthy" bycaught $D$. delphis not suffering for any infectious or non-infectious disease that would inhibit reproduction, a significant increase in corpora number with age was observed in sexually mature individuals - although the sample size was small ( $p=0.002, r^{2}=0.44, n=19$; Fig. 6). Corpora number ranged from 1 to $16(n=23)$ in mature females, which is in contrast to the high scar numbers observed within the BIOCET data (Table 2). $40 \%$ of mature female BIOCET D. delphis had $\geq=17$ corpora scars and $70 \%$ had $\geq=11$ corpora scars (range 1-34). Within the control group, all sexually immature (nulliparous) females (range 17.2-93.6 $\mu \mathrm{g} \mathrm{g}^{-1}$ lipid) and the three "primiparous" pregnant females (range 32.3-77.82 $\mu^{-1} g^{-1}$ lipid) had total blubber PCB levels above the threshold level (Fig. 7a, b). The two aged "primiparous" pregnant females were 8 and 10 years old. Although not significant - though similar to the results obtained using the BIOCET harbour porpoise data - a decline in PCB burden with increasing corpora number was observed in mature females (Fig. 7b), and a similar plot was obtained when $\sum 18$ PCBs was plotted against corpora number (not shown). Further, a non-significant decline in DDT burden against corpora number was also observed (Fig. 7c).

\section{Discussion}

\section{Accumulation and persistence of corpora scars}

Many of the common dolphins and harbour porpoises in the present study had high numbers of corpora albicantia in their ovaries and we can be reasonably certain that these could not all indicate past pregnancies, which suggests that CAs from infertile ovulations are common in free-ranging small cetacean populations. Takahashi et al. (2006) reported that collagenous fibrous tissue in regressing corpora lutea from $D$. delphis off Japan was replaced by elastin tissue, a material which has a reported half life of 40-70 years. They were unable to differentiate CAs from pregnancy with those from ovulation, and it was assumed that smaller CAs, containing $<15 \%$ elastin, were derived from infertile ovulations. With a reproductive period of $c a 19$ years reported for the ENA D. delphis population (Murphy et al., 2009b), results from Takahashi et al. (2006) study suggest that CAs, of pregnancy at least, do persist throughout the lifetime of a female common dolphin.

Pregnant and pregnant \& lactating female BIOCET D. delphis had significantly lower number of corpora scars than resting mature females. In contrast, a lack of significant variation was observed in corpora number
P. phocoena

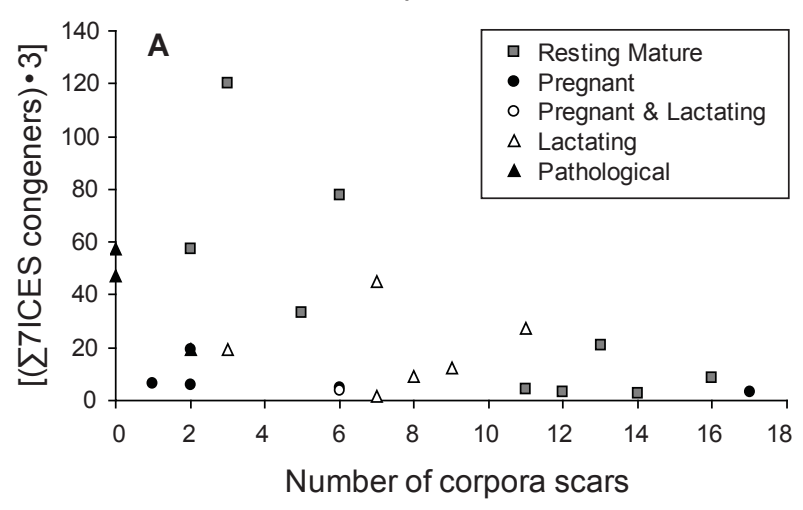

D. delphis

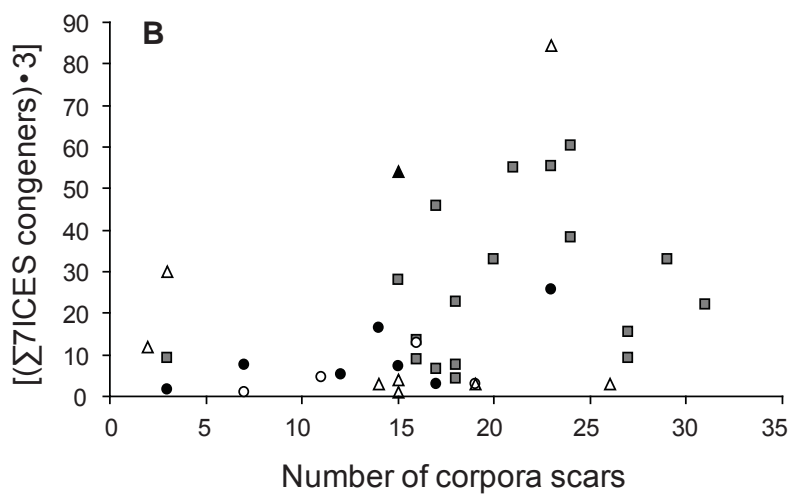

Fig. 5. The total number of corpora scars (corpora albicantia and corpora lutea) in sexually mature ovaries as a function of PCB burden [( $\sum$ 7ICES congeners $\left.) \cdot 3\right]$ in (A) BIOCET P. phocoena $(n=24)$, and (B) BIOCET D. delphis $(n=38)$.

between reproductive groups in BIOCET $P$. phocoena. In addition, the number of corpora scars in porpoise ovaries tended to be lower than in common dolphins, at a given age after attaining sexual maturity (Fig. 2). Within the BIOCET sample, the estimated annual pregnancy rate (APR) in P. phocoena (42\%) was higher than in D. delphis (25\%) (Pierce et al., 2008), and the calving interval (using the BIOCET data) for $P$. phocoena $(1 / \mathrm{APR}=2.4$ years $)$ is much shorter than in D. delphis (4 years). Note however that the APR for $P$. phocoena is almost certainly underestimated from strandings, being incompatible with mortality rate data (J. Learmonth, pers. comm.), whereas the APR for D. delphis is similar to that proposed for the ENA population (26\%; Murphy et al., 2009b). These data suggest that harbour porpoises are pregnant more of the time than common dolphins, and would therefore possibly ovulate less; common dolphins are more likely to undergo repeated unsuccessful ovulations during their extended calving interval. This difference in number of corpora scars may also be related to social organisation, 


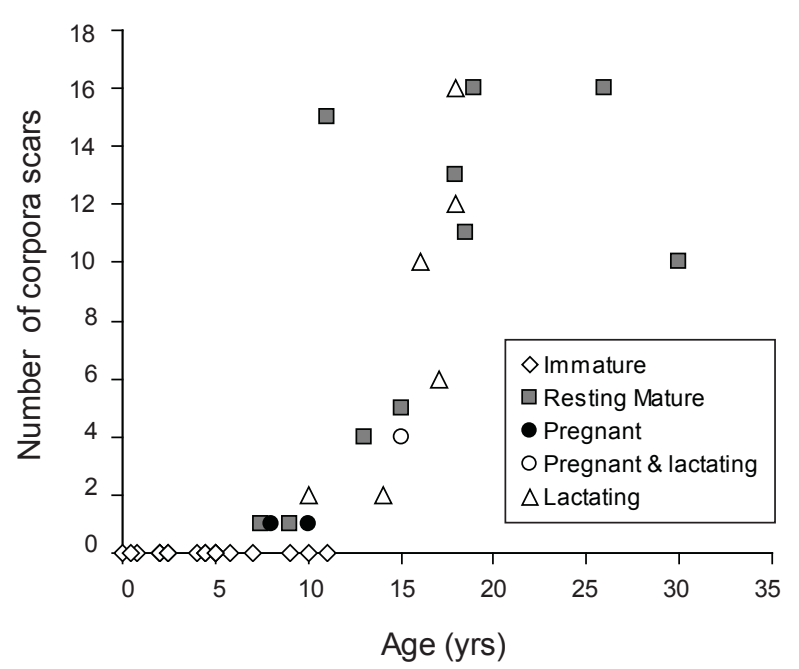

Fig. 6. The total number of corpora scars (corpora albicantia and corpora lutea) as a function of age in the $D$. delphis $(n=38)$ control group sample.

i.e. porpoises do not form large social groups (outside the breeding period) so the occurrence of fertile non-breeders undergoing multiple ovulations is less likely, or as a result of a number of other life history and population traits (and/or variations in species capabilities to metabolise PCBs by cytochrome P-450).

In D. delphis off the French Atlantic coast, Dabin et al. (2008) suggested that all ovarian scars do not persist, and their number at any one time would be a function of rates of ovulation and healing, the latter being defined here as the resorption or disintegration of CA tissue. CA counts differed between individuals of distinct reproductive status. Pregnant $(\mathrm{CA}$ counts $=8.8 \pm 5.9$, range $1-22, n=32$ ) and pregnant/lactating females $(\mathrm{CA}$ counts $=11.3 \pm 4.9$, range $5-18, n=6)$ exhibited lower numbers of CAs than those observed in resting mature females $(\mathrm{CA}$ counts $=15.4 \pm 8.6$, range $1-34, n=60)$, which is similar to the BIOCET sample in current study. Dabin et al. (2008) proposed that most CAs would heal quickly, with a half-life of $<1$ year (the time after which half of the CA has disappeared), though larger CAs (possibly from pregnancy) may persist longer than smaller CAs (possibly from unsuccessful ovulations). This was based on the following observations: CA number did not increase significantly with age; pregnant $D$. delphis had ca $40 \%$ fewer scars than non-pregnant animals; and since all pregnant individuals were sampled between January and March, prior to the estimated calving period for the population. In contrast, studies undertaken on other populations of D. delphis, by Danil and Chivers (2007) in the eastern tropical Pacific, Westgate and Read (2007) in the western North Atlantic and Takahashi et al. (2006) in
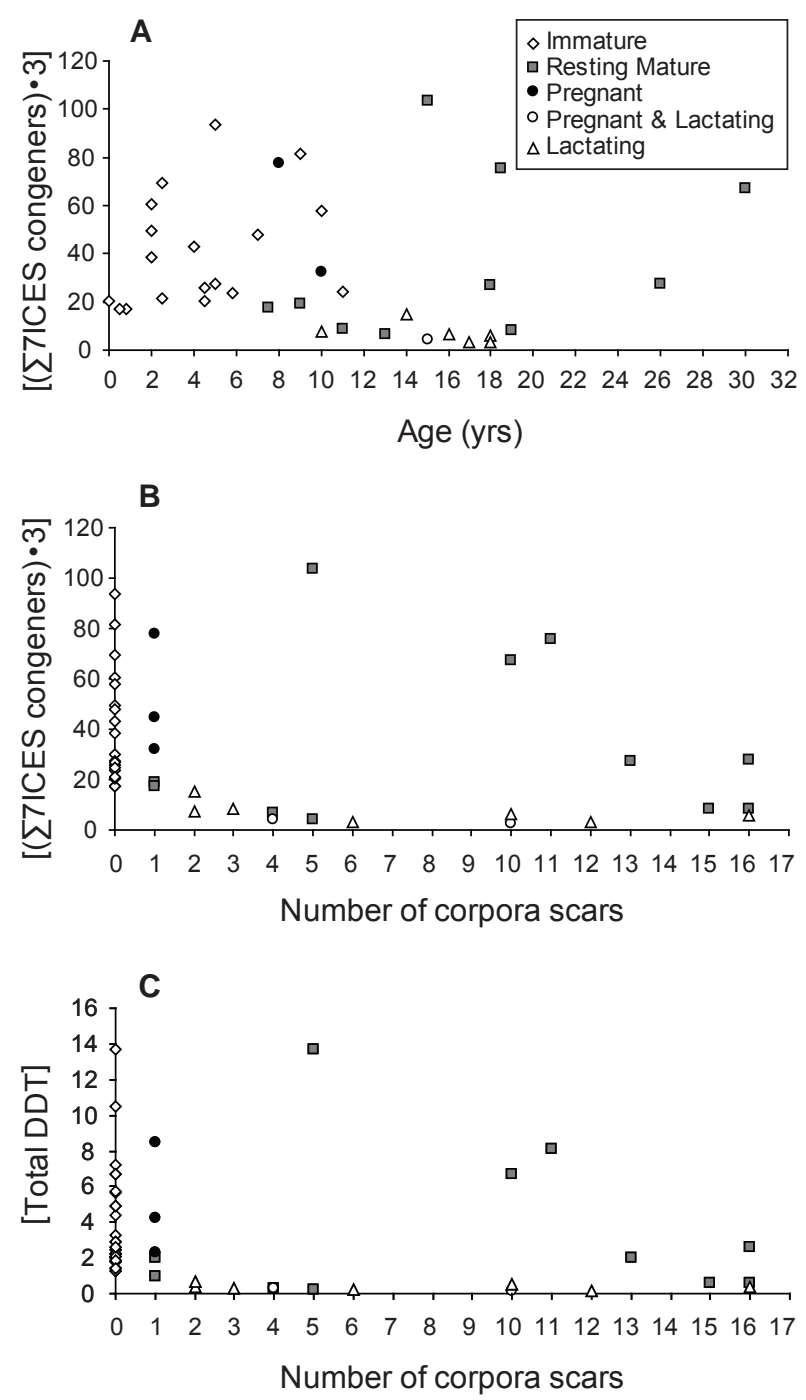

Fig. 7. PCB burden $\left[\left(\sum 7 \mathrm{ICES}\right.\right.$ congeners $\left.) \cdot 3\right]\left(\mu \mathrm{g} \mathrm{g}^{-1}\right.$ lipid $)$ as a function of (A) age $(n=38)$, and $(\mathbf{B})$ number of corpora scars $(n=43)$; (C) total DDT burden function of number of corpora scars $(n=43)$ in the D. delphis control group sample.

waters off Japan have all reported a significant increase in corpora number with age.

Both D. delphis and P. phocoena in the ENA appear to have a more extended mating/conception period than other populations inhabitating temperate waters. Mating and calving periods in $D$. delphis and $P$. phocoena have been reported from May to September (Murphy, MS 2004) and May to August (Learmonth, MS 2006), respectively, although peaks in reproductive activity were noted in both populations (Murphy, MS 2004; Murphy et al., 2005; Learmonth, MS 2006). Repeated ovulations during a nine month period ( 7 ovulations) have been observed in 
a captive $D$. delphis (Kirby and Ridgeway, 1984), though it is not known if this individual was obtained from a population that exhibited reproductive seasonality. Off the Irish coast, mature and pubertal female $D$. delphis were only reported ovulating during the mating period, May to September (6 out of 45 individuals examined; Murphy, MS 2004). With a reproductive cycle lasting ca 27 days (range 17-36 days; Robeck et al., 2005; Atkinson and Yoshioka, 2007) in Tursiops truncatus, P. phocoena and D. delphis in the ENA could undergo four and five infertile ovulations, respectively, within their mating periods. However shorter or longer estrus cycles may occur - estrus cycles of 31 days $(n=22)$ have been reported in Pacific white-sided dolphins (Lagenorhynchus obliquidens) (Robeck et al., 2009). Gross and histological examination of ovarian material for $D$. delphis off the Irish coast suggested that two individuals had ovulated five times within one estrus period (Murphy, MS 2004). In both cases these dolphins died during September, and for one individual the final ovulation had resulted in pregnancy.

In the Dabin et al. (2008) study, lactating D. delphis had the highest numbers of CAs with an average number of 20 scars (range $11-26, n=8$ ), slightly higher than that obtained in lactating BIOCET $D$. delphis in the current study (average $=15.5$, range $2-26, n=12$ ). Although these sample sizes are small, results do not suggest a CA half-life of less than one year; taking into account the estimated lactation period for this population is 10.4 months (Murphy, MS 2004), a gestational period of ca 12 months (Murphy et al., 2009b) and reproductive seasonality i.e. not ovulating outside the mating season. In contrast, a significantly lower number of corpora scars (Mann-Whitney test, $p=0.046, n=19$ ) were reported in the ovaries of lactating $D$. delphis in the control group sample (average $=7.3$, range $=2-16, n=7$ ) compared to lactating BIOCET $D$. delphis. Furthermore, a significantly lower number of corpora scars (Mann-Whitney test, $p=0.0007, n=51)$ were observed in the ovaries of resting mature $D$. delphis in the control group (average $=8.8$, range $=1-16, n=11$ ), compared to the resting mature BIOCET D. delphis (average $=17.8$, range $=2-34$, $n=40$ ). Interestingly, there was no significant difference in corpora scar number between resting mature $D$. delphis in the control group, and pregnant $D$. delphis in the BIOCET sample $($ average $=9.4$, range $=1-23, n=20)$. One BIOCET French resting mature individual, which was part of the mass live stranding event at Pleubian, had 31 ovarian scars and was aged at only 8 years. It cannot be ruled out that some corpora albicantia present on the ovaries of this individual could be as a result of accessory corpora lutea and/or ovulatory disorders, though further (histological) analysis is required to fully account for the high scar number in this young mature female.
In $D$. delphis, it has been suggested sexual maturity can be marked by the onset of a variable number of successive estrus cycles not resulting in pregnancy (Collet and Harrison, 1981). Gaskin et al. (1984) reported multiple CAs in four and five-year old $P$. phocoena from the Bay of Fundy, ranging from 1-12 and 2-15 scars, respectively; individuals attain sexual maturity between two and four years of age in this population (Read, 1990). Further, as can be seen in Fig. 2, large-scale individual variation also occurred in corpora count data at a given age for both BIOCET P. phocoena and D. delphis. For example, at four years of age corpora number ranged from 1 to 7 scars in mature $P$. phocoena. These data suggest multiple infertile ovulations at the onset of sexual maturity in some individuals. However, within the control group sample only one corpora scar was present in the ovaries of the three "primiparous" females, aged 8 and 10 years, thus indicating that $D$. delphis can become pregnant after only one estrus cycle.

The variation in number of ovarian scars at a given age and/or ovulation rates between individuals and the lack of correlation between age and corpora number for the D. delphis and P. phocoena BIOCET samples, does suggest the possibility of resorption of corpora scars. In addition to resorption though, the large individual variation in corpora scar count data may also be as a consequence of (1) variation in age at attainment of sexual maturity between individuals; (2) variations in estrus cycle length; (3) ovulatory disorders; (4) health status of the female, some females might not be capable in conceiving or carrying foetuses to full term due to poor nutritional condition, disease, infection, or other pathological reasons; (5) length of time before a young mature female attains the status of breeding "cow" within the social structure, as during this time a variable number of successive estrus cycles not resulting in pregnancy could occur (Collet and Harrison, 1981); and (6) the possibility of breeding and non-breeding mature females within $D$. delphis social groups, as non-pregnant females may not reproduce but help in the nursing of calves. Therefore, females that were unable to become pregnant either as a result of age, dominance hierarchies (a higher probability for $D$. delphis) or poor health could continue to ovulate (infertile ovulations) and accumulate higher numbers of corpora scars.

It has been noted in short-finned pilot whales (Globicephala macrorhynchus) that, although CAs are believed to be retained indefinitely, estimating the rate of accumulation of scars is difficult because of variation in the age at attainment of sexual maturity and variation in the ovulation rate within an individual's reproductive lifespan (Marsh and Kasuya, 1984). Interestingly, within 
the control group of "healthy" individuals, a significant positive correlation between age and corpora number was observed in mature female $D$. delphis, though some data scattering was observed (Fig. 6). Further, a significantly lower number of CAs were observed in the ovaries of the $D$. delphis control group sample compared to the BIOCET D. delphis sample (Mann-Whitney test, $p=0.0001, n=109$; Table 2). As 53\% of the mature BIOCET D. delphis sample with corpora count data was obtained from a single mass live stranding event in Pleubian in 2002, this may have caused potential biases within that sample. For the majority of mature individuals in the control group an increase in corpora scar number $(\geq 4$ CAs) was not obvious until after 15 years of age. Therefore once other factors that may effect reproduction such as various infectious and non-infectious diseases and poor nutritional status were taken account, individuals appeared to ovulate less. Whether or not this reflects a lower number of unsuccessful ovulations in these "healthy" females, i.e. pregnant more often, necessitates further investigation. Only one animal was reported in poor nutritional condition in the control group, which is the oldest aged female within the ENA population. The individual in question was a 30-year old resting mature female with both a high contaminant burden of $67.4 \mu \mathrm{g} \mathrm{g}^{-1}$ lipid [( $\sum$ 7ICES congers $\left.) \cdot 3\right]$ and corpora scar number (10 CAs). Following a live stranding event the female was euthanised and the postmortem examination revealed evidence of recent net entanglement; the poor nutritional status was attributed to a period of starvation as a result of the traumatic injuries sustained.

Inconsistencies were observed between both species in the current study. Apart from P. phocoena displaying lower numbers of corpora scars at a given age after attaining sexual maturity, they also exhibited lower right ovarian activity. There may also be inter-species differences in persistence of ovarian scars, as the presence of elastin has not been assessed in harbour porpoise CAs. In Hawaiian monk seals (Monachus schauinslandi), as collagenous fibrous tissues are not replaced by elastic fibrous tissues, CAs (including pregnancy) do not persist (Iwasa and Atkinson, 1996). Further, data obtained from a long-term study using ultrasound on a captive bottlenose dolphin indicated that corpus albicans derived from a corpus luteum of pregnancy persist in the ovaries, while those arising from infertile ovulations completely disintegrate and, are ultimately resorbed (Brook et al., 2002). The individual examined ovulated 18 times over a 12-year period in captivity, and produced three calves. At death, aged 18 years, only three corpora albicantia were recorded, measuring 3-4 $\mathrm{mm}$ in diameter. In contrast, gross and histological examinations revealed $c a 15 \mathrm{CAs}$ on the ovaries of another bottlenose dolphin, that was known to have at least five ovulations and one calf in captivity (Kirby and Ridgeway, 1984).

Data within the current study do not add further proof to theory of resorption of corpora scars, nor suggest an average half-life (the time after which half of the CAs has disappeared) of $<1$ year for a $\mathrm{CA}$. The higher number of corpora scars present on the ovaries of resting mature females within the BIOCET sample could be attributed to a higher number of infertile ovulations for a number of reasons, as outlined earlier. In addition: (1) corpora scar number increased significantly with age in the D. delphis control group sample of "healthy" individuals, (2) a lack of significant variation in corpora count data between resting mature $D$. delphis in the control group and pregnant D. delphis in the BIOCET sample, and (3) no significant variation in corpora count data between pregnant and resting mature $P$. phocoena. Even though taking in account these results, we have not fully disproved the theory of resorption and further investigations are required to assess the disintegration/resorption of CAs at a histological level in both species. Based on these results we believe that it is acceptable to use number of corpora scars as an index of reproductive activity, though we do take into consideration the biases that may result from this approach.

\section{Effects of POPs on reproductive activity}

For the BIOCET data in the current study, D. delphis with the highest PCB burdens (and above the threshold level) were resting mature females (not pregnant or lactating). Further, these individuals also had the highest number of scars of ovulation on their ovaries, which suggested that due to high contaminant burdens female common dolphins may be unable to reproduce and thus, continue ovulating; or females are not reproducing for some other reason, either physical or social, and started accumulating higher levels of contaminants in their blubber. The high associated PCB burden may thus be either (or both) the cause of infertility or the consequence of infertility. In contrast in harbour porpoises, once the effect of age and nutritional condition were taken into account, the data so far suggests that higher POP concentrations (PCB, HBCD and DDE) tended to be associated with lower numbers of corpora scars, possibly indicating that high contaminant levels were inhibiting ovulation.

Redundancy analysis undertaken on the BIOCET data by Pierce et al. (2008) indicated that the number of corpora albicantia $(p=0.007)$ and incidence of pregnancy $(p=0.029)$ were related to concentrations of POPs (PCBs, PBDEs and DDE; excluding HBCDs) in the blubber tissue of $D$. delphis. In contrast, reproductive variables 
were not related to concentrations of POPs in the blubber of harbour porpoises although there were relationships between the latter and concentrations of zinc and other heavy metals. In humans, infection has been associated with zinc redistribution, and high concentrations observed in the liver were due to acute-phase protein synthesis (Scott, 1986; Amdur et al., 1991; Pierce et al., 2008). Further, as high concentrations of Zinc have previously been associated with poor health in P. phocoena (Das et al., 2004), it was used to provide an index of the poor health status in this species in the Pierce et al. (2008) study; cause of death was determined for $68 \%$ of the P. phocoena BIOCET POP sample and of this, 57\% died from pathological causes. A causal (immunotoxic) relationship has been reported between PCB exposure and infectious disease mortality in UK harbour porpoises (Jepson et al., 2005). Among adult stranded female $P$. phocoena, PCB levels were significantly higher in individuals classified in the infectious disease group than in animals classified in the physical trauma group (died from incidental capture and bottlenose dolphin attacks), and females dying of infectious disease had significantly poorer nutritional status (relative body weight and mean blubber thickness) compared to the physical trauma group (Jepson et al., 2005). This casual immunotoxic relationship may therefore have masked any direct affects of POPs, through lowering immunity, on reproductive activity/output in P. phocoena in the current study.

In order to eliminate any affects of infectious and noninfectious disease on reproductive activity, contaminant data and gonadal material were analysed from a control group of "healthy" $D$. delphis. The threshold for adverse health effects in marine mammal, of $17 \mu \mathrm{g} \mathrm{g}^{-1}$ lipid was applied to these data, [( $\sum 7 \mathrm{ICES}$ congers $\left.) \cdot 3\right]$, in order to provide a benchmark for interpreting whether associations between reproductive activity and PCB exposure are biologically significant. Within the control group, all sexually immature (nulliparous) females (range 17.2-93.6 $817 \mu \mathrm{g} \mathrm{g}^{-1}$ lipid) and the three primiparous pregnant females (range 32.3-77.817 $\mu \mathrm{g} \mathrm{g}^{-1}$ lipid) had contaminant loads above the threshold level, suggesting that high PCB burdens are not inhibiting ovulation, conception or implantation in D. delphis. As mentioned previously, Reijnders $(1986,2003)$ reported a decrease in reproductive success in harbour seals which was possibly due to implantation disruption. However, as pinnipeds experience delayed implantation/embryonic diapause, they may be more vulnerable than cetaceans at this stage of the reproductive cycle. Studies on mink (Mustela vison) have also reported that PCBs can impair reproduction; although ovulation, conception and implantation occur, fetues died during gestation or shortly after birth (Jensen et al., 1977; Reijnders, 1986; Backlin and Bergman, 1992,
1995; Schwacke et al., 2002). This was attributed to either hormonal disturbance, direct dominant-lethal action or to an embryo lethal effect caused by toxicants (Reijnders, 1986). It should be noted that the Kannan et al., (2000) PCB threshold of $17 \mu \mathrm{g} \mathrm{g}^{-1}$ lipid is less protective than that proposed of $10 \mu \mathrm{g} \mathrm{g}^{-1}$ lipid, which was associated with increased calf mortality in wild bottlenose dolphins (Hall et al., 2006b; Hickie et al., 2007). Further, the analysis in the current study only assessed the effects of $16 \mathrm{CB}$ congeners on reproductive activity, and did not include the most immunotoxic IUPAC congeners, such as CB77 and $\mathrm{CB} 126$.

Relative low-level exposures to some chemicals at critical life stages can result in dramatic effects on individuals, and/or subtle but important population-wide impacts, by affecting population growth, maintenance and/or health (O'Hara and O'Shea, 2005). The three primiparous $D$. delphis females in the current study were within their second trimester, and it is not known whether all three females would have successfully given birth and/or the survival rate of their first born calves. In female Californian sea lions, associations have been documented between high OC levels in post parturient individuals and miscarriages, and premature pupping during the last two trimesters of pregnancy. The majority of premature pups are born alive during the third trimester, but all die within several hours of birth (Marine Mammal Commission, 1999). However, the association between OCs and prematurity is confounded by the presence of disease capable of inducing abortions: serological evidence of leptospirosis and calicivirus has been found. Further, the frequency of prematurity was higher during El Niño years, indicating that the nutritional status of the females also influences the probability of prematurity (Marine Mammal Commission, 1999).

Interestingly, species-level differences in effects of condition (blubber thickness) on corpora number were observed, with an almost linear positive effect reported in BIOCET D. delphis compared to a negative effect in BIOCET $P$. phocoena. Thus $P$. phocoena in good nutritional condition (increased blubber thickness) had lower number of corpora scars whereas for D. delphis, individuals in good nutritional condition had higher number of corpora scars. On assessing the BIOCET D. delphis data further, $92 \%(12 / 13)$ of mature individuals with contaminant burdens above the threshold level (all but two individuals were resting mature) and corresponding high corpora count data ( $\geq 15$ scars), were obtained from the mass live stranding event in Pleubian in February 2002. Of the 52 individuals necropsied in this mass stranded group, only one male (calf) was present and all other individuals were female, including four nursing 
calves. Results from genetic analysis on the Pleubian group reported a lack of evidence for a matriarchal system, with genetic variability within the mass-stranded group similar to variability observed in single strandings i.e. common dolphins were not necessarily genetically related (Viricel et al., 2008). Therefore, the existence of non-reproductive females (based on high contaminant loads and high numbers of ovulations) within this social group is even more remarkable; though it should be noted that the whole mass-stranded group was not sampled for genetic analysis, as 50 other individuals were released alive offshore.

The most parsimonious interpretation of the negative relationship between POP concentrations with increasing corpora number in the $D$. delphis control group and also in resting mature female BIOCET $P$. phocoena, is that a high number of corpora scars indicates infertility or a high level of miscarriages/abortions (repeated ovulations as the animal does not get pregnant, or loses the foetus during gestation or soon after), and some females may go through a large number of infertile ovulations prior to a successful pregnancy, birth, and survival of their first offspring during early lactation - as mentioned previously, females offload ca $80 \%$ of their OC burden during the first seven weeks of lactation (Cockcroft et al., 1989). A high foetal mortality rate in the first trimester (40-67\%) has been reported in other small delphinids (Stenella longirostris and Stenella attenuata), which was attributed to adverse interactions with purse seine fisheries in the eastern tropical Pacific; induction of miscarriage due to physiological stress of chase and capture or indirectly through depletion of energy stores (Perrin et al., 2003). Data in the current study may also suggest the existence of non-breeding (ovulating) females in the population, although it appears that most females eventually become pregnant - due to a decline in the contaminant levels with increasing corpora number in the control group and BIOCET P. phocoena sample, though this does not appear to be the case within the Pleubian mass stranding group. Although the number of corpora scars increased with age within the D. delphis control group sample, the problems in deciphering whether or not corpora albicantia provide a lifetime record of past ovulations has caused difficulties in correctly interpreting these data. Future work will assess the effects of contaminants on foetal survival rates in both species, and also the indirect effects of contaminants, through lower immunity, on reproductive activity.

\section{Acknowledgements}

This work was part funded by the EC-funded BIOCET project (BIOaccumulation of persistent organic pollutants in small CETaceans in European waters: transport pathways and impact on reproduction, EVK32000-00027); the UK Department for Environment, Food and Rural Affairs under SLA23; and the Agreement on the Conservation of Small Cetaceans of the Baltic, North East Atlantic, Irish and North Seas (ASCOBANS). The UK Cetacean Strandings Investigation Programme (CSIP) funded by Defra as part of its commitment to the ASCOBANS, supported attendance at strandings and necropsies for UK animals. We thank Tony Patterson and Rod Penrose for their contributions to data collection in the UK. In Ireland, members of the Irish Whale and Dolphin Group assisted with data collection. Jérôme Spitz and other members of CRMM assisted with collection of samples from the French Atlantic coast. Claude Joiris, Jean-Marie Bouquegnau and Ludo Holsbeek kindly provided access to Belgian samples. Members of CEMMA attended strandings in Galicia. We are also grateful for the collaboration of the Dutch strandings network. We thank two anonymous referees for useful comments on the manuscript.

\section{References}

AGUILAR, A. 1985. Compartmentation and reliability of sampling procedures in organochlorine pollution surveys of cetaceans. Residue Rev., 95: 91-114.

AGUILAR, A., A. BORRELL, and T. PASTOR. 1999. Biological factors affecting variability of persistent pollutant levels in cetaceans. J. Cetacean Res. Manag., Special Issue 1: 83-116.

AGUILAR, A., A. BORRELL, and P. J. H. REIJNDERS. 2002. Geographical and temporal variation in levels of organochlorine contaminants in marine mammals. Mar. Environ. Res., 53: 425-452. doi:10.1016/S01411136(01)00128-3

AMDUR, M. O., J. DOULL, and C. D. KLAASSEN. 1991. Toxicology: the Basic Science of Poisons. McGraw-Hill, New York, $1074 \mathrm{p}$.

ANDERSEN, L. W., D. E. RUZZANTE, M. WALTON, P. BERGGREN, A. BJORGE, and C. LOCKYER. 2001. Conservation genetics of harbour porpoises, Phocoena phocoena, in eastern and central North Atlantic. Conserv. Biol., 2: 309-324.

ANDERSEN, W. L. 2003. Harbour porpoise (Phocoena phocoena) in the North Atlantic: distribution and genetic population structure. In: Harbour Porpoises in the North Atlantic. NAMMCO Scientific publications, Volume 5, T. Haug, G. Desportes, G. Vikingsson, and L. Witting (eds.). p. $11-29$

AMARAL MENDES, J. J. 2002. The endocrine disrupters: a major medical challenge. Food Chem. Toxicol., 40: 781-788. doi:10.1016/S0278-6915(02)00018-2

ATKINSON, S., and M. YOSHIOKA. 2007. Endocrinology of reproduction. In: Reproductive biology and phylogeny of Cetacea. Whales, dolphins and porpoises, D. L. Miller (ed.). Science Publishers, p. 171-192.

BACKLIN, B. M., and A. BERGMAN. 1992. Morphological 
aspects on reproductive organs in female mink (Mustela vison) exposed to polychlorinated biphenyls and fractions thereof. Ambio, 21: 596-601.

1995. Histopathology of postpartum placental sites in mink (Mustela vison) exposed to polychlorinated biphenyls or fractions there of. APMIS, 103: 843-854. doi:10.1111/j.1699-0463.1995.tb01443.x

BREDHULT, C., B.-M. BÄCKLIN, A. BIGNERT, and M. OLOVSSON. 2008. Study of the relation between the incidence of uterine leiomyomas and the concentrations of PCB and DDT in Baltic gray seals. Reprod. Toxicol., 25: 247-255. doi:10.1016/j.reprotox.2007.11.008

BROOK, F. M., R. KINOSHITA, and K. BENIRSCHKE. 2002. Histology of the ovaries of a bottlenose dolphin, Tursiops truncatus, of known reproductive history. Mar. Mamm. Sci., 18: 540-544. doi:10.1111/j.1748-7692.2002.tb01054.x

COCKCROFT, V. G., A. C. DE KOCK, D. A. LORD, and G. J. B. ROSS. 1989. Organochlorines in bottlenose dolphins Tursiops truncatus from the east coast of South Africa. S.Afr. J. Mar. Sci., 8: 207-217.

COLlET, A., and R. J. HARRISON. 1981. Ovarian characteristics, corpora lutea and corpora albicantia in Delphinus delphis stranded on the Atlantic coast of France. Aquat. Mamm., 8: 69-76.

DABIN, W., F. COSSAIS, G. PIERCE, and V. RIDOUX. 2008. Do ovarian scars persist with age in all Cetaceans: new insight from the short-beaked common dolphin (Delphinus delphis Linnaeus , 1758). Mar. Biol., 156: 127-139. doi:10.1007/s00227-008-1070-4

DANIL, K., and S. J. CHIVERS. 2007. Growth and reproduction of female short-beaked common dolphins, Delphinus delphis, in the eastern tropical Pacific. Can. J. Zool., 85: 108-121. doi:10.1139/Z06-188

DAS, K., U. SIEBERT, M. FONTAINE, T. JAUNIAUX, L. HOLSBEEK, and J. M. BOUQUEGNEAU, 2004. Ecological and pathological factors related to trace metal concentrations in harbour porpoises Phocoena phocoena from the North Sea and adjacent areas. Mar. Ecol. Prog. Ser., 281: 283-295.

DE GUISE, S., A. LAGACE, and P. BELAND. 1994. True hermaphroditism in a St. Lawrence beluga whale (Delphinapterus leucas). J. Wildl. Dis., 30: 287-190.

DELONG, R. L., W. G. GILMARTIN, and J. G. SIMPSON. 1973. Premature births in California Sea Lions: Association with high organochlorine pollutant residue levels. Science, 181: 1168-1170. doi:10.1126/science.181.4105.1168

EVANS, P.G.H.,L.W.ANDERSEN,A.BJØRGE, M.FONTAINE, A. GALATIUS, C. C. KINZE, C. LOCKYER, C. DE LUNA, G. J. PIERCE, S. SVEEGAARD, J. TEILMANN, R. TIEDEMANN, and M. WALTON. 2009. Harbour porpoise Phocoena phocoena. Report of ASCOBANS/ HELCOM small cetacean population structure workshop. 8-10 October 2007, UN Campus, Hermann-Ehlers-Str. 10, 53113 Bonn, Germany, p. 61-85.

FONTAINE, M. C., S. J. E. BAIRD, S. PIRY, N. RAY, K. A. TOLLEY, S. DUKE, A. BIRKUN JR, M. FERREIRA, T. JAUNIAUX, A. LLAVONA, B. OZTURK, A. A. OZTURK, V. RIDOUX, E. ROGAN, M. SEQUEIRA, U. SIEBERT, G. A. VIKINGSSON, J.-M. BOUQUEGNEAU, and J. R. MICHAUX. 2007. Rise of oceanographic barriers in continuous populations of a cetacean: the genetic structure of harbour porpoises in old world waters. $B M C$ Biol., 5: 30. doi:10.1186/1741-7007-5-30

GASKIN, D. E., G. J. D. SMITH, A. P. WATSON, W. Y. YASUI, and D. B. YURICK. 1984. Reproduction in the porpoises (Phocoenidae): implications for management. In: Reproduction in whales, dolphins and porpoises, W. F. Perrin, R. L. Brownell, Jr, and D. P. DeMaster (eds.). International Whaling Commission, Cambridge, $\mathrm{p}$. $135-148$.

HALL, A. J., K. HUGUNIN, R. DEAVILLE, R. J. LAW, C. R. ALLCHIN, and P. D. JEPSON. 2006a. The risk of infection from polychlorinated biphenyl exposure in the harbor porpoise (Phocoena phocoena): A case-control approach. Environ. Health Perspect., 114: 704-711. doi:10.1289/ ehp. 8222

HALL, A. J., B. J. MCCONNELL, T. K. ROWLES, A. AGUILAR, A. BORRELL, L. SCHWACKE, P. J. H. REIJNDERS, and R. S. WELLS. 2006b. Individual-based model framework to assess population consequences of polychlorinated biphenyl exposure in bottlenose dolphins. Environ. Health Perspect., 114 (Suppl 1): 60-64. doi:10.1289/ehp.8053

HARRISON, R. J., R. L. BROWNELL, and R. C. BOICE. 1972. Reproduction and gonadal appearance in some odontocetes. In: Functional anatomy of marine mammals. R. J. Harrison (eds.). Academic press Inc., London, p. 362-429.

HASTIE, T. J., and R. J. TIBSHIRANI. 1990. Generalized additive models. Chapman and Hall, London, 352 p.

HELLE, E. 1976. PCB Levels correlated with pathological changes in seal uteri. Ambio, 5: 261-263.

HELLE, E., M. OLSSON, and S. JENSEN. 1976. DDT and PCB levels and reproduction in ringed seal from Bothnian Bay. Ambio, 5: 188-189.

HICKIE, B. E., D. MACKAY, and J. DE KONING. 1999. Lifetime pharmacokinetic model for hydrophobic contaminants in marine mammals. Environ. Toxicol. Chem., 18: 2622-2633. doi:10.1002/etc.5620181132

HICKIE, B. E., M. C. S. KINGSLEY, P. V. HODSON, D. C. G. MUIR, P. BÉLAND, and D. MACKAY. 2000. A modellingbased perspective on the past, present, and future polychlorinated biphenyl contamination of the St. Lawrence beluga whale (Delphinapterus leucas) population. Can. J. Fish. Aquat. Sci., 57: 101-112.

HICKIE, B. E., P. S. ROSS, R. W. MACDONALD, and J. K. B. FORD. 2007. Killer whales (Orcinus orca) face protracted health risks associated with lifetime exposure to PCBs. Environmen. Sci. Technol., 41: 6613-6619. doi:10.1021/ es0702519

HOHN, A. A., R. Y. EWING, and J. ZAIAS. 2007. Reproduction in relation to conservation and commercial exploitation. In: Reproductive biology and phylogeny of cetacea. Volume 7 of series: Reproductive biology and phylogeny. D. L. Miller (ed.). Science Publishers, Enfield, p. 371-389.

ICES WGMME. 2005. Report of the Working group on marine mammal ecology. 9-12 May 2005, Savolinna, Finland.

IWASA, M., and S. ATKINSON. 1996. Analysis of corpora lutea to estimate reproductive cycles of wild Hawaiian monk seals (Monachus schauinslandi). Mar. Mamm. Sci., 
12: 182-198. doi:10.1111/j.1748-7692.1996.tb00570.x

JENSEN, S., J. E. KILSTROM, M. OLSSON, C. LUNDBERG, and J. ORBERG. 1977. Effects of PCB and DDT on mink (Mustela vison) during reproductive season. Ambio, 6. 229-239.

JEPSON, P. D. (Ed.). 2005. Cetacean Strandings Investigation and Co-ordination in the UK 2000-2004. Final report to the Department for Environment, Food and Rural Affairs. p. 1-79. http://www.defra.gov.uk/wildlife-countryside/ resprog/findings/index.htm.

JEPSON, P., P. M. BENNETT, R. DEAVILLE, C. R. ALLCHIN, J. R. BAKER, and R. J. LAW. 2005. Relationships between polychlorinated biphenyls and health status in harbour porpoises (Phocoena phocoena) stranded in the United Kingdom. Environ. Toxicol. Chem., 24: 238-248. doi:10.1897/03-663.1

KANNAN, K., A. L. BLANKENSHIP, P. D. JONES, and J. P. GIESY. 2000. Toxicity reference values for the toxic effects of polychlorinated biphenyls to aquatic mammals. Hum. Ecol. Risk Assess., 6: 181-201. doi:10.1080/10807030091124491

KIRBY, V. L., and S. H. RIDGEWAY. 1984. Hormonal evidence of spontaneous ovulation in captive dolphins, Tursiops truncatus and Delphinus delphis. In: Reproduction of Whales, Dolphins and Porpoises, W. F. Perrin, R. L. Brownell, Jr, and D. P. DeMaster (eds.). International Whaling Commission, Cambridge, p. 459-464.

KUIKEN, T., and M. GARCIA HARTMANN. 1991. Proceedings of the first European Cetacean Society workshop on "Cetacean pathology: dissection techniques and tissue sampling". Europ. Cetacean Soc. Newslet., 17: 1-39.

LEARMONTH, J. A. MS 2006. Life history and fatty acid analysis of harbour porpoises (Phocoena phocoena) from Scottish waters. PhD Thesis, University of Aberdeen.

LEARMONTH, J. A., S. MURPHY, W. DABIN, M. ADDINK, A. LOPEZ, E. ROGAN, V. RIDOUX, A. GUERRA, and G. J. PIERCE. MS 2004. Measurement of reproductive output in small cetaceans from the Northeast Atlantic. BIOCET workpackage 5 - final report. Project Reference: EVK3-2000-00027. 53

LOCKYER, C. 1995. A review of factors involved in zonation in odontocete teeth, and an investigation of the likely impact of environmental factors and major life events on harbour porpoise tooth structure. In: Biology of the Phocoenids, A. Bjorge, and G. P. Donovan (eds.). International Whaling Commission, Cambridge, p. 511-529.

MARINE MAMMAL COMMISSION. 1999. Marine mammals and persistent ocean contaminants: Proceedings of the Marine Mammal Commission workshop, Keystone, Colorado. 12-15 October 1998. 150 p. + vii.

MARSH, H., and T. KASUYA. 1984. Changes in the ovaries of short-finned pilot whales, Globicephala macrorhyuchus, off the Pacific coast of Japan. In: Reproduction in whales, dolphins and porpoises, W. F. Perrin, R. L. Brownell, Jr, and D. P. DeMaster (eds.). International Whaling Commission, Cambridge, p. 311-336.

MARTINEAU, D., P. BÉLAND, C. DESJARDINS, and A. LAGACÉ. 1987. Levels of organochlorine chemicals in tissues of beluga whales (Delphinapterus leucas) from the
St. Lawrence Estuary, Quebec, Canada. Arch. Environ. Con. Tox., 16: 137-147. doi:10.1007/BF01055795

MURPHY, S. 2004. The biology and ecology of the common dolphin Delphinus delphis in the North-east Atlantic. Ph. D. thesis, University College Cork.

MURPHY, S. MS 2008. Investigating biological parameters in common dolphins and harbour porpoises. Annex to final report to the UK Department for Environment Food and Rural Affairs, Project MF0736, Sea Mammal Research Unit. 38p.

MURPHY, S., A. COLLET, and E. ROGAN. 2005. Mating strategy in the male common dolphin Delphinus delphis: what gonadal analysistellsus.J.Mammal.,86: 1247-1258. doi:10.1644/15451542(2005)86[1247:MSITMC]2.0.CO;2

MURPHY, S., A. NATOLI, A. R. AMARAL, L. MIRIMIN, A. VIRICEL, F. CAURANT, P. G. H. EVANS, R. HOELZEL, and J. TEILMANN 2009a. Short-beaked common dolphin Delphinus delphis. Report of ASCOBANS/HELCOM small cetacean population structure workshop. 8-10 October 2007, UN Campus, Hermann-Ehlers-Str. 10, 53113 Bonn, Germany. 111-130.

MURPHY, S., A. WINSHIP, W. DABIN, P. D. JEPSON, R. DEAVILLE, R. J. REID, C. SPURRIER, E. ROGAN, A. LÓPEZ, A. GONZÁLEZ, F. READ, M. ADDINK, M. SILVA, V. RIDOUX, J. A. LEARMONTH, G. J. PIERCE, and S. P. NORTHRIDGE. 2009b. The importance of biological parameters in assessing the current status of the short-beaked common dolphin Delphinus delphis in the eastern North Atlantic. Mar. Ecol. Prog. Ser., 388: 273-291. doi:10.3354/meps08129

O'HARA, T. M., and T. J. O'SHEA. 2005. Assessing impacts of environmental contaminants. In: Marine mammal research: Conservation beyond crisis, J. E. Reynolds, W. F. Perrin, R. Reeves, S. Mpntgomery, and T. J. Ragen (eds.). The Johns Hopkins University Press, Baltimore, p. 63-83.

OLSSON, M., B. KARLSSON, and E. AHNLAND. 1994. Diseases and environmental contaminants in seals from the Baltic and the Swedish west coast. Sci. Total Environ., 154: 217-227. doi:10.1016/0048-9697(94)90089-2

ÓLAFSDÓtTIR, D., G. A. VÍKINGSSON, S. D. HALLDÓRSSON, and J. SIGURJÓNSSON. 2003. Growth and reproduction in harbour porpoises (Phocoena phocoena) in Icelandic waters. In: Harbour porpoises in the North Atlantic. Nammco Scientific Publications Volume 5, T. Huag, G. Desportes, G. A. Víkingsson, and L. Witting (eds.). The North Atlantic Marine Mammal Commission, Tromso, p. 195-210.

PERRIN, W. F., CHIVERS, S. J. AND ARCHER, F. I. 2003. Fetal mortality in dolphins exploited by the tuna fishery. In: Abstracts of the 15th Biennial Conference on the Biology of Marine Mammals, Greensboro, NC., 14-19 December 2003. The Society for Marine Mammalogy.

PERRIN, W. F., and G. P. DONOVAN. 1984. Report of the workshop. In: Reproduction of Whales, Dolphins and Porpoises, W. F. Perrin, R. L. Brownell, Jr , and D. P. DeMaster (eds.). International Whaling Commission., Cambridge, p. 1-24.

PERRIN, W. F., and S. B. REILLY. 1984. Reproductive parameters of dolphins and small whales of the family 
Delphinidae. In: Reproduction of Whales, Dolphins and Porpoises, W. F. Perrin, R. L. Brownell, Jr, and D. P. DeMaster (eds.). International Whaling Commission, Cambridge, p. 97-134.

PIERCE, G. J., M.B. SANTOS, S. MURPHY, J.A.LEARMONTH, A. F. ZUUR, E. ROGAN, P. BUSTAMANTE, F. CAURANT, V. LAHAYE, V. RIDOUX, B. N. ZEGERS, A. METS, M. ADDINK, C. SMEENK, T. JAUNIAUX, R. J. LAW, W. DABIN, A. LOPEZ, J. M. ALONSO FARRE, A. F. GONZALEZ, A. GUERRA, M. GARCIAHARTMANN, R. J. REID, C. F. MOFFAT, C. LOCKYER, and J. P. BOON. 2008. Bioaccumulation of persistent organic pollutants in female common dolphins (Delphinus delphis) and harbour porpoises (Phocoena phocoena) from western European seas: Geographical trends, causal factors and effects on reproduction and mortality. Environ. Pollut., 153: 401-415. doi:10.1016/j.envpol.2007.08.019

READ, A. J. 1990. Age at sexual maturity and pregnancy rates of harbour porpoises Phocoena phocoena from the Bay of Fundy. Can. J. Fish. Aquat. Sci., 47: 561-565. doi:10.1139/ f90-064

READ, A. J., and A. A. HOHN. 1995. Life in the fast lane: the life history of harbour porpoises from the Gulf of Maine. Mar. Mamm. Sci., 11: 423-440. doi:10.1111/j.1748-7692.1995. tb00667.x

REDDY, M. L., J. S. REIF, A. BACHAND, and S. H. RIDGWAY. 2001. Opportunities for using Navy marine mammals to explore associations between organochlorine contaminants and unfavorable effects on reproduction. Sci. Total Environ., 274: 171-182. doi:10.1016/S0048-9697(01)00741-0

REIJNDERS, P. J. H. 1980. Organochlorine and heavy metal residues in harbour seals from the Wadden sea and their possible effects on reproduction. Neth. J. Sea Res., 14: 30-65. doi:10.1016/0077-7579(80)90012-5

REIJNDERS, P. J. H. 1986. Reproductive failure in common seals feeding on fish from polluted coastal waters. Nature, 324: 456 457. doi: $10.1038 / 324456 \mathrm{a} 0$

REIJNDERS, P. J. H. 1999. Reproductive and developmental effects of endocrine-disrupting chemicals on marine mammals. In: Marine mammals and persistent Ocean Contaminants. T. J. O'Shea, R. Reeves, and A. K. Long (eds.). Proc. Mar. Mamm. Comm. Workshop, Keystone, Colorado, 12-15 October 1998, p. 93-99.

REIJNDERS, P. J. H. 2003. Reproductive and developmental effects of environmental organochlorines on marine mammals. In: Toxicology of marine mammals, J. G. Vos, G. D. Bossart, D. A. Fournier, and T. J. O'Shea (eds.). Taylor and Francis, London, p. 55-66.

ROBECK, T. R., K. J. STEINMAN, M. GREENWELL, K. RAMIREZ, W. VAN BONN, M. YOSHIOKA, E. KATSUMATA, L. DALTON, S. OSBORN, and J. K. O'BRIEN. 2009. Seasonality, estrous cycle characterization, estrus synchronization, semen cryopreservation, and artificial insemination in the Pacific white-sided dolphin (Lagenorhynchus obliquidens). Reprod., 138: 391-405. doi:10.1530/REP-08-0528

ROBECK, T. R., K. J. STEINMAN, M. YOSHIOKA, E. JENSEN, J. K. O’BRIEN, E. KATSUMATA, C. GILI, J.
F. MCBAIN, J. SWEENEY, and S. L. MONFORT. 2005. Estrous cycle characterisation and artificial insemination using frozen-thawed spermatozoa in the bottlenose dolphin (Tursiops truncatus). Reprod., 129: 659-674. doi:10.1530/ rep. 1.00516

ROGAN, E., S. MURPHY, J.A. LEARMONTH,A. GONZÁLEZ, and W. DABIN. MS 2004. Age Determination in small cetaceans from the NE Atlantic. BIOCET workpackage 4 final report. Project Reference: EVK3-2000-00027, 34 p.

ROSS, P. S. 2000. Marine mammals as sentinels in ecological risk assessment. Hum. Ecol. Risk Assess., 6: 29-46. doi:10.1080/10807030091124437

ROSS, P. S., G. M. Ellis, M. G. IKONOMOU, L. G. BARRETT-LENNARD, and R. F. ADDISON. 2000. High PCB concentrations in free-ranging Pacific killer whales, Orcinus orca: Effects of Age, Sex and Dietary Preference. Mar. Pollut. Bull., 40: 504-515. doi:10.1016/ S0025-326X(99)00233-7

SANTOS, M. B., J. A. LEARMONTH, G. J. PIERCE, C. F. MOFFAT, E. ROGAN, S. MURPHY, V. RIDOUX, L. MEYNIER, V. LAHAYE, C. PUSINERI, and J. SPITZ. MS 2004b. Dietary studies on small cetaceans in the NE Atlantic using stomach contents and fatty acid analyses. BIOCET workpackage 6 - final report. Project reference: EVK3-2000-00027, 99 p.

SANTOS, M. B., G. J. PIERCE, J. A. LEARMONTH, R. J. REID, H. M. ROSS, I. A. P. PATTERSON, D. G. REID, and D. BEARE. 2004. Variability in the diet of harbor porpoises (Phocoena phocoena) in Scottish waters 1992-2003. Mar. Mamm. Sci., 20: 1-27. doi:10.1111/j.1748-7692.2004. tb01138.x

SANTOS, M. B., G. J. PIERCE, LOPEZ A, M. T. MARTINEZ, M. T. FERNANDEZ, E. IENO, E. MENTE, P. PORTEIRO, P. CARRERA, and M. MEIXIDE. MS 2004a. Variability in the diet of common dolphins (Delphinus delphis) in Galician waters 1991-2003 and relationships with prey abundance. ICES CM 2004/Q:9.

SCHWACKE, L. H., E. O. VOIT, L. J. HANSEN, R. S. WELLS, G. B. MITCHUM, A. A. HOHN, and P. A. FAIR. 2002. Probabilistic risk assessment of reproductive effects of polychlorinated biphenyls on bottlenose dolphins (Tursiops truncatus) from the Southeast United States coast. Environ. Toxicol. Chem., 21: 2752-2764.

SCOTT, M. L. 1986. Nutrition of humans and selected animal species. John Wiley, New York, 537 p.

SØRENSEN, T. B., and C.C. KINZE. 1994. Reproduction and reproductive seasonality in Danish harbour porpoises, Phocoena phocoena. Ophelia, 39: 159-176.

STEWART, E. A., and B. E. STEWART. 2003. Female reproductive systems. In: Encyclopedia of marine mammals. W. F. Perrin, B. Wursig, and J. G. M. Thewissen (eds.). Academic press, London, p. 422-428.

TAKAHASHI, Y., S. OHWADA, K. WATANABE, Y. ROPERT-COUDERT, R. ZENITANI, Y. NAITO, and T. YAMAGUCHI. 2006. Does elastin contribute to the persistence of corpora albicantia in the ovary of the common dolphin (Delphinus delphis). Mar. Mamm. Sci., 22: 819-830. doi:10.1111/j.1748-7692.2006.00050.x 
VIRICEL, A., A. STRAND, P. ROSEL, V. RIDOUX, and P. GARCIA. 2008. Insights on common dolphin (Delphinus delphis) social organization from genetic analysis of a mass-stranded pod. Behav. Ecol. Sociobiol., 63: 173-185. doi:10.1007/s00265-008-0648-7

WALTON, M. J. 1997. Population structure of harbour porpoises Phocoena phocoena in the seas around the UK and adjacent waters. Proc. R. Soc. Lond. (B: Biol. Sci.), 264 (1378): 89-94. doi:10.1098/rspb.1997.0013

WELLS, R. S., V. TORNERO, A. BORRELL, A. AGUILAR, T. K. ROWLES, H. L. RHINEHART, S. HOFMANN, W. M. JARMAN, A. A. HOHN, and J. C. SWEENEY. 2005. Integrating life-history and reproductive success data to examine potential relationships with organochlorine compounds for bottlenose dolphins (Tursiops truncatus) in
Sarasota Bay, Florida. Sci. Total Environ., 349: 106-119. doi:10.1016/j.scitotenv.2005.01.010

WESTGATE, A. J., and A. J. READ. 2007. The life history of short-beaked common dolphins (Delphinus delphis) in the western North Atlantic. Mar. Biol., 150: 1011-1024. doi:10.1007/s00227-006-0394-1

YLitAlo, G. M., C. O. MATKIN, J. BUZITIS, M. M. KRAHN, L. L. JONES, T. ROWLES, and J. E. STEIN. 2001. Influence of life-history parameters on organochlorine concentrations in free-ranging killer whales (Orcinus orca) from Prince William Sound, AK. Sci. Total Environ., 281: 183-203. doi:10.1016/S00489697(01)00846-4

ZUUR, A.F., E. N. IENO, G. M. SMITH. 2007. Analysing Ecological Data. Springer, Berlin, 672 p. 